\title{
Chemical composition and pharmacological significance of Anethum Sowa L. Root
}

\author{
Md Moshfekus Saleh-e-In ${ }^{*}$, Nasim Sultana², Md Matiur Rahim³ ${ }^{3}$ Md Aminul Ahsan², Md Nurul Huda Bhuiyan³, \\ Md Nur Hossain ${ }^{4}$, Md Mahbubar Rahman ${ }^{5}$, Sudhangshu Kumar Roy ${ }^{6}$ and Md Rabiul Islam
}

\begin{abstract}
Background: Medicinal herbs are used for the treatment of different ailments since antiquity. Different parts of Anethum sowa L. is used in folk medicine as a carminative for the treatment of flatulence, colic and hiccups of infants and children, antioxidant, antimicrobial and antispasmodic agent. The aim of our present study is to evaluate the chemical composition of the essential oil, proximate and elemental composition, amino acid, fatty acid profile and thermal behaviour of its root part as well as different pharmacological activities like antioxidant, antimicrobial and cytotoxicity of the root essential oil.
\end{abstract}

Methods: The air-dried roots of Anethum sowa L. were subjected to hydro-distillation to yield the essential oil. The antioxidant activity of the essential oil was studied by DPPH radical scavenging activity. The antimicrobial activity was tested against four Gram-positive, six Gram-negative bacteria and four fungi species. The minimum inhibitory concentration (MIC) and Minimum bacterial concentration (MBC) for each examined microorganism were determined using the micro-dilution method. The $\mathrm{LC}_{50}$ value of the oil was also evaluated by brine shrimp lethality assay. The subsequent proximate analysis was also done by AOAC methods. The elemental analysis of the root powder was analysed by ICP-MS, AAS and FP system. The fatty acid was extracted by hot and cold extraction method and the analyses were carried out by GC. The amino acid profile was done by the amino acid analyzer. The DTA, DTG and TG of the root powder were taken by the thermogravimetric analyzer.

Results: A total of 24 constituents was identified and quantified in the essential oil and its water extract portion by GC and GC-MS. Apiol (81.99 and 74.779\%) was found the highest phenylpropanoid constituent followed by m-diaminobenzene (10.446 and 8.778\%) in the essential oil and aqueous extract portion. On the other hand, $\beta$-butyrolactone (5.13\%) and isobutyl acetone (3.73\%) were found in the major constituents in the water extract part. The $\boldsymbol{I}_{50}$ value of the essential oil was found to be $3.07 \mathrm{mg} / \mathrm{mL}$ by DPPH radical assay methods. The $L C_{50}$ value of the brine shrimp cytotoxicity assay of the essential oil was observed at $0.81 \mathrm{\mu g} / \mathrm{mL}$. The essential oil showed better activity on Gram-negative bacteria than Gram-positive bacteria and fungi. The proximate composition showed that root contained 5.29\% ash, 2.01\% protein, 54 . 09\% crude fibre, $0.15 \%$ essential oil and $1.14 \%$ fatty oil for hot extract and $0.23 \%$ for cold extract on the dried basis. The palmitic (33.81 \& 31.58\%) and linoleic acid (30.03 \& 23.79\%) were the major saturated and unsaturated fatty acids in the cold and hot extracted root powder respectively. Ca $(23,600 \mathrm{mg} / \mathrm{kg}), \mathrm{Mg}(7620.33 \mathrm{mg} / \mathrm{kg})$ and $\mathrm{K}(1286.15 \mathrm{mg} / \mathrm{kg})$ were the most predominant elements followed by Ni (1187.30 mg/kg), Se (913.79 mg/kg), Li (317.84 mg/kg), Na (288.72 mg/kg) and Fe $(206.88 \mathrm{mg} / \mathrm{kg})$. The toxic elements were found to be within the permissible limit. Glutamic acid (19.37\%), glycine (14. 53\%) and lysine (17.08\%) were found as the major amino acids. The decomposition rates were obtained by TG, DTG and DTA curve of the powder sample at various temperature ranges.

(Continued on next page)

\footnotetext{
* Correspondence: saleheen.sosthe@gmail.com

'Department of Chemistry, Jahangirnagar University, Savar, 1342 Dhaka,

Bangladesh

Full list of author information is available at the end of the article
}

(c) The Author(s). 2017 Open Access This article is distributed under the terms of the Creative Commons Attribution 4.0 International License (http://creativecommons.org/licenses/by/4.0/, which permits unrestricted use, distribution, and reproduction in any medium, provided you give appropriate credit to the original author(s) and the source, provide a link to the Creative Commons license, and indicate if changes were made. The Creative Commons Public Domain Dedication waiver (http://creativecommons.org/publicdomain/zero/1.0/) applies to the data made available in this article, unless otherwise stated. 
(Continued from previous page)

Conclusions: The results demonstrated that the root part of Anethum sowa L. is a rich source of mineral elements, essential amino acid and fatty acids. The essential oil is the highly potential as bioactive oil for pharmaceuticals and medical applications, possessing antioxidant, antimicrobial and cytotoxic activities. The thermal analysis suggested as a simple, effective and rapid method to characterize the Anethum sowa L. species as well as to assess for herbal formulation.

Keywords: Anethum sowa L, Amino acid, Apiol, Biological activity, Fatty acid, ICP/MS, Thermal analysis

\section{Background}

Herbs and spices, grown wildly in various regions of the world have been used for culinary and medicinal purposes since ancient times. Anethum sowa L. (BengaliShulfa) belonging to the family Apiaceae (Umbelliferae), comes under genus Anethum and it is an annual and winter spice crop in Bangladesh. It is mostly grown in the northern part of Bangladesh. A variant called Indian dill or sowa (Anethum sowa Roxb.) is largely cultivated in Bangladesh, India, Egypt and Japan. Indigenous people consume it as a spice for a flavouring agent in food preparation. The herb grows ordinarily $2-2.5 \mathrm{ft}$. in height with small feathery leaves, tapped and branched roots $[1,2]$. The chemical composition of the essential oil of the two chemotypes i.e. European dill (Anethum graveolens L.) and Indian dill (Anethum sowa L.) are differentiated mainly by the apiol and carvone content. Anethum sowa is rich in apiol whereas Anethum graveolens is rich in carvone. The typical flavor of dill herb oil is due to $\alpha$-phellandrene, limonene and dill ether (anethofuran) [3]. The green herb, seeds and its roots are used as folkloric medicine e.g. aromatic, carminative especially useful in the treatment of flatulence, colic and hiccups of infants and children [4]. Recently, it has been reported that seed essential oils are the potential source of antioxidant and also have antimicrobial and antispasmodic properties [5].

Due to commercial interest, extensive studies have been done on dill seed (fruit) and weed (herb) essential oil for its sensory qualities, physical and chemical composition. Very few reports [6-9] have been found in the essential oil and mineral content of the root part of Anethum graveolens L (Dill) species to the best of our knowledge. But the chemical composition and pharmacological studies of Anethum sowa root are still to the unveiled. Therefore, the aims of this study were to elucidate the chemical composition as well as its pharmacological activities of the essential oil, elemental composition, amino acid, fatty acid profile and thermal behavior of its root part. This information can be helpful in the formulation of various herbal forms of medicines.

\section{Methods}

\section{Plant material}

Whole plants were collected from Keranigonj, Dhaka of Bangladesh after harvesting. The plants were taxonomically classified and identified scientifically by Dr. Sardar Nasir Uddin, PSO, Bangladesh National Herbarium Centre, Dhaka, Bangladesh. A voucher specimen of the plant was preserved in Bangladesh National Herbarium Centre with the Accession Number-31,282. Root samples were chopped into small pieces, dried in a shade by air and ground to powder by grinding machine (100 mesh) and finely stored in an air tight high-density polyethylene bag.

\section{Physico-chemical and proximate studies}

The physicochemical and proximate studies were carried out with three replications by the standard methods [10-12].

\section{Extraction of fatty acids}

Fatty acid extraction of the root powder was carried out by Soxhlet apparatus with hexane in a temperature controlled heating mantle for $72 \mathrm{~h}$ (working time) as per Soxhlet method [13] and simultaneously a cold extraction was carried out successively by petroleum ether (b.p. $40-60{ }^{\circ} \mathrm{C}$ ) at room temperature. All extractions were carried out three times and evaporated the residual solvent by Buchi rotary evaporator at low temperature and reduced pressure.

\section{Fatty acid analysis}

The fatty acid composition was determined by analysis of their methyl esters. The fatty acid methyl esters (FAMEs) of the hot and cold extracted fatty acids were prepared through esterification by using $\mathrm{BF}_{3}$. $\mathrm{MeOH}$ complex, according to the AOAC method [14].

\section{Instrument and separation conditions of the fatty acids}

Fatty acid methyl esters were analysed and identified by using Shimadzu 2025 Gas Chromatograph with a Flame Ionization Detector and GC Work Station Software. A fused capillary column $\mathrm{AT}^{\mathrm{mm}}-1(30 \mathrm{~m} \times 0.25 \mathrm{~mm}$ I.d. and $0.1 \mu \mathrm{m}$ film thickness) was used for separation. Helium was used as carrier gas, at a flow rate of $2 \mathrm{~mL} / \mathrm{min}$. Injection and detector temperature was $250{ }^{\circ} \mathrm{C}$. The oven temperature was programmed at $120^{\circ} \mathrm{C}-270{ }^{\circ} \mathrm{C}$ by raising the temperature at $7{ }^{\circ} \mathrm{C} / \mathrm{min}$. Split ratio was 80 . The fatty acid compounds were identified by comparison of relative retention times and peak positions of the standard fatty acid chromatogram. Atherogenic Index (AI) and 
Thrombogenic Index (TI) were calculated according to Ulbricht and Southgate [15] which $\mathrm{AI}$ is $\mathrm{C}_{12: 0}+$ $\left(4 \times \mathrm{C}_{14: 0}\right)+\mathrm{C}_{16: 0} /$ PUFA + MUFA and TI is $\mathrm{C}_{14: 0}+\mathrm{C}_{16: 0}+$ $\mathrm{C}_{18: 0} / 0.5 \times \mathrm{MUFA}+0.5 \times$ PUFA.

\section{Amino acid analysis}

The root powder sample $(5.0 \mathrm{~g})$ was refluxed with $6 \mathrm{M}$ $\mathrm{HCl}(50 \mathrm{~mL})$ at $110{ }^{\circ} \mathrm{C}$ for $24 \mathrm{~h}$ for protein hydrolysis. Then the solution was kept in an evaporating dish to evaporate $\mathrm{HCl}$ on a water bath. The residue was again dissolved in $20 \mathrm{~mL} 0.1 \mathrm{M} \mathrm{HCl}$ and evaporation was repeated twice to remove excess of the acid. It was then filtered through Whatman No. 1 filter paper with $0.1 \mathrm{M}$ $\mathrm{HCl}$ in a volumetric flask which was known as a stock solution. Again, the stock solution was filtered through $0.45 \mu \mathrm{m}$ syringe filter with pressure for amino acid analysis [16]. Then the stock and standard solutions were run through Shimadzu amino acid analyzer with a fluorescent detector. The sample amino acids were identified by comparing with standard amino acids retention times and calculated the percentage of their individual areas.

\section{Elemental analyses}

\section{Reagents, water and standard}

Nitric acid $\left(\mathrm{HNO}_{3}\right)$ of trace metal analysis grade, hydrochloric acid $(\mathrm{HCl}) 37 \%$ of $\mathrm{BDH}$, analar grade and high purity de-ionized water from the Barnstead purification system were used throughout the study. Multi-element stock solutions containing $10 \mathrm{mg} / \mathrm{L}$ of each element were obtained from USA (Accu Trace TM Reference Standard).

ICP-MS tuning solution: Contains $10 \mathrm{ppb} \mathrm{Ba}, \mathrm{Be}, \mathrm{Ce}$, $\mathrm{Co}, \mathrm{In}, \mathrm{Pb}, \mathrm{Mg}, \mathrm{Tl}$ and $\mathrm{Th}$ for instrument tuning and verification of performance.

Metals stock standard for ICP-MS:10 mg/L (Reference / Traceable) of metals $\mathrm{Be}, \mathrm{Bi}, \mathrm{Cd}, \mathrm{Cs}, \mathrm{Cr}, \mathrm{Co}, \mathrm{Cu}, \mathrm{Ga}, \mathrm{In}$, Li, Ni, Pb, As, Se and Ag.

Preparation of working standard for calibration: Working standard were prepared of 1, 5, 10, 20 and $50 \mu \mathrm{g} / \mathrm{L}$ from $100 \mu \mathrm{g} / \mathrm{L}$ intermediate standard by $1 \%$ $\mathrm{HNO}_{3}$ diluents for carrying out analysis.

\section{Ashing procedure and sample preparation for ICP-MS and AAS}

A certain amount of moisture less sample powder was taken. Ashing and subsequent sample preparation were performed as per AOAC method [10].

\section{ICP-MS instrument and operating condition}

The elemental analyses were done by Varian UltraMass ${ }^{\text {тм }}$ ICP-MS system (Varian Optical Spectroscopy Instruments, Melbourne Australia). The plasma source was 99.998\% argon (Carbagas 3097, Liebefeld, Bern, Switzerland). All operating parameters were under computer control. Operating conditions of the instrument are depicted in Table 1.
Table 1 Operating conditions of Varian ICP-MS

\begin{tabular}{ll}
\hline Parameters & Settings \\
\hline Plasma conditions & \\
RF power & $1.40 \mathrm{~kW}$ \\
Plasma Ar flow rate. & $18.0 \mathrm{~L} \mathrm{~min}^{-1}$ \\
Auxiliary Ar flow rate & $2.25 \mathrm{~L} \mathrm{~min}^{-1}$ \\
Sheath gas flow & $0.20 \mathrm{~L} \mathrm{~min}^{-1}$ \\
Nebulizer gas flow & $1.0 \mathrm{~L} \mathrm{~min}^{-1}$ \\
Sampling depth & $6.50 \mathrm{~mm}^{-1}$ \\
Pump Rate & $5 \mathrm{rpm}$ \\
Instrument & \\
Sampler cone: Nikel & $1.0 \mathrm{~mm}$ orifice diameter \\
Skimmer cone: Nikel & $0.5 \mathrm{~mm}$ orifice diameter \\
\hline
\end{tabular}

\section{Atomic absorption spectrometry (AAS) analyses}

$\mathrm{Mg}, \mathrm{Fe}, \mathrm{Mn}$ and $\mathrm{Ca}$ were analysed by Flame Atomic Absorption Spectrometer (Varian AA 240 FS). Al was analyzed by Zeeman Atomic Absorption Spectrometer (Varian AA $240 \mathrm{Z}$ ) in graphite furnace and the total $\mathrm{Hg}$ was analyzed by cold vapor hydrate generation Atomic Absorption Spectrometer (Varian AA 220 FS) followed by the Varian operating manual. The metal stock standard for $\mathrm{Mg}, \mathrm{Fe}, \mathrm{Ca}, \mathrm{Al}$ and $\mathrm{Mn}$ were $1000 \mathrm{mg} / \mathrm{L}$ (Reference/Traceable) and quantification limit for the elements were at ppm levels. The detection limit for Fe, $\mathrm{Mn}$ and $\mathrm{Al}$ are $0.027,0.005$ and $0.00196 \mathrm{mg} / \mathrm{mL}$ respectively. On the other hand, $\mathrm{Hg}$ stock standard was AR grade of equivalent $100 \mathrm{mg} / \mathrm{L}$. The quantification limit for the total $\mathrm{Hg}$ was $0.01 \mu \mathrm{g} / \mathrm{L}$ (ppb). All calibrated standard, quality control standard and check standard are traceable to National Institute of Standard and Technology (NIST). Recovery of quality spiked sample, duplicate samples and quality control sample were observed. The recovery ranges for each parameter were $100 \pm 10 \%$.

\section{Flame photometry analyses}

The concentration of $\mathrm{Na}$ and $\mathrm{K}$ were analysed by Flame Photometer (Jenway PFP-7, England, UK), CRM (Certified Reference Material). Standard (ranging from 1 to $5 \mathrm{ppm}$ ) of $\mathrm{Na}^{+}$and $\mathrm{K}^{+}$solution were used in the serial dilution method for standard curve within linear calibration range and total quantities in samples were calculated.

\section{Thermogravimetric analysis}

TG/DTA 6300 (The Seiko Instrument, USA) thermo gravimetric analyzer was used for monitoring continuous weight change of root powder due to drying, volatilisation and gasification and followed a linear heating program. The DTG and DTA curves were recorded in terms of percentage weight loss per minute and temperature difference in $\mathrm{mV}$ (for DT). Powder sample (7.34 $\mathrm{mg})$ was heated in a platinum crucible under the 
furnace atmosphere at a heating rate of $20{ }^{\circ} \mathrm{C} / \mathrm{min}$ up to the final temperature performed of $800{ }^{\circ} \mathrm{C}$. The $\alpha-\mathrm{Al}_{2} \mathrm{O}_{3}$ $(6 \mathrm{mg})$ was used as a reference material.

\section{Extraction of essential oils}

A. sowa root was subjected to hydro-distillation using Clevenger's apparatus [17] for $4 \mathrm{~h}$. Emulsified water soluble constituents were extracted with ethyl acetate and dried under high vacuum rotary evaporator at $35^{\circ} \mathrm{C}$. Both oils were then dried over anhydrous magnesium sulphate and stored at $4{ }^{\circ} \mathrm{C}$ prior to analysis.

\section{GC-MS analysis}

The essential oils were analysed by Electron Impact Ionization (EI) method on GC-2010 Shimadzu Gas Chromatograph, coupled to a GC-MS QP 2010 plus Shimadzu Mass Spectrometer fitted with RTX-5 MS fused silica capillary column (Supelco Inc.) (30 $\mathrm{m} \times$ $2.5 \mathrm{~mm} ; 0.25 \mu \mathrm{m}$ film thickness). The column temperature was $40{ }^{\circ} \mathrm{C}$ (hold $2 \mathrm{~min}$ ) to $220^{\circ} \mathrm{C}$ (hold $5 \mathrm{~min}$ ) at the rate of $10^{\circ} \mathrm{C} / \mathrm{min}$, maintained with carrier gas helium at a constant pressure of $90 \mathrm{kPa}$ (Acquisition parameters full scan; scan range $40-550 \mathrm{amu}$ ). The split ratio was 10 . Mass spectra were taken at $70 \mathrm{eV}$.

\section{Identification of the compounds}

The constituents of the essential oil were identified by retention indices under temperature-programmed conditions based on co-injection of homologous n-alkanes $\left(\mathrm{C}_{6}-\mathrm{C}_{24}\right)$ on the RTX-5 MS capillary column. Compounds were identified by comparison of their mass spectra with those of the internal reference mass spectral NIST-107 library.

\section{Antioxidant activity}

The antioxidant activity of the root essential oil on the stable radical 1, 1-diphenyl-2-picrylhydrazyl (DPPH) (0.2 Mmol) (Sigma-Aldrich) was determined by the BrandWilliams method [18] with some modifications. The oil was dissolved in methanol and applied concentrations were 46.5 to $0.36328 \mathrm{mg} / \mathrm{mL}$ by serial dilution technique. Ascorbic acid (ASA) and tert-butyl-1-hydroxytoluene (BHT) were used as positive control. The absorbance was measured at $517 \mathrm{~nm}$ using an Analytic Jene Spekel 1300 UV spectrophotometer. The per cent of inhibitions were calculated from the equation:

$$
\% \text { inhibition }=\left(1-\mathrm{ABS}_{\text {sample }} / \mathrm{ABS}_{\text {control }}\right) \times 100
$$

The data of $\mathrm{IC}_{50}$ values were transformed into a straight line by means of a trend line fit linear regression analysis by MS Excel version 7 Software for windows.

\section{Cytotoxic activity of brine shrimp lethality bioassay}

In vitro Brine Shrimp lethality bioassay of the essential oil was exploited to detect cytotoxicity by Mayer's method [19]. Brine Shrimp eggs were hatched in the brine solution $(3.8 \% \mathrm{NaCl}$ in distilled water) within $48 \mathrm{~h}$. The samples were prepared by dissolving in DMSO solution (not more than $50 \mu \mathrm{L}$ in $5 \mathrm{~mL}$ solution) and it was applied in $5 \mathrm{~mL}$ brine solution to attain the concentrations of 0.0195 to $10.0 \mu \mathrm{g} / \mathrm{mL}$. DMSO $(50 \mu \mathrm{L})$ was used as negative control. Standard vincristine sulphate (VcS) $(0.078 \mu \mathrm{g} / \mathrm{mL}$ to $10.0 \mu \mathrm{g} / \mathrm{mL})$ was used as positive control. Approximately 10 matured nauplii were taken to each vial. The numbers of surviving nauplii were counted after $24 \mathrm{~h}$. The lethal concentrations $\left(\mathrm{LC}_{50}\right)$ and the dose-response data were calculated by Biostate 2007 data analysis software.

\section{Antimicrobial activity test}

The antimicrobial activity of the essential oil was determined by diffusion and dilution method [20] against 4 gram-positive (Bacillus subtilis, Staphylococcus aureus, Bacillus cereus, Enterococcus faecalis), 6 gram-negative bacteria (Salmonella typhi, E. coli 12079, E. coli 2799, Pseudomonas aeruginosa, Salmonella enteritidis, Acetobacter aceti) and 4 fungi (Candida albicans, Aspergillus niger, Sacharomyces cerevaceae and Trichoderma sp.) species.

\section{Diffusion method}

The test microbes were taken from the broth culture with an inoculating loop and transferred to the test tubes containing $5.0 \mathrm{~mL}$ sterile distilled water. The microbial suspension turbidity was adjusted to McFarland standard number 0.5, in Mueller Hinton Broth (Himedia, India). A cotton swab was then used to inoculate the test tube suspension onto the surface of the Mueller Hinton agar plates and the plates were allowed to dry. The agar was allowed to set and harden. Holes were made by using a sterile cork borer from each petriplate to ensure proper distribution of holes (cups) in the periphery and one in the centre. Agar plugs were removed. Different cork borers were used for different test organisms. Two standard discs (6 $\mathrm{mm}$ in diameter) were transferred onto the agar surface by using sterile forceps. Each hole was impregnated with $40 \mu \mathrm{L}$ of a sample solution containing 400, 600 and $800 \mu \mathrm{g}$ sample. This was done also for methanol (negative control) as a blank. These plates were kept for half an hour at a low temperature so that the test materials were diffused to the surrounding medium by this time. The plates were then incubated at $37{ }^{\circ} \mathrm{C}$ for $20 \mathrm{~h}$. The diameter of the inhibition zone against each microorganism was measured by slide calipers and compared the results with standard 
antibiotic ciprofloxacin (5 $\mu \mathrm{g} / \mathrm{disc})$ and tetracycline (30 $\mu \mathrm{g} /$ disc) (positive control).

\section{Dilution method (MIC and MBC determination)}

Minimum Inhibitory Concentrations (MIC) and Minimum Bactericidal Concentrations (MBC) assays were carried out on the essential oil by the macro-dilution method [21, 22]. The essential oil was dissolved in $30 \%$ dimethyl sulfoxide (DMSO) to obtain $10 \%(\mathrm{w} / \mathrm{v})$ solution. For MIC test of the selected bacteria, the essential oil was first diluted in sterilized Mueller-Hinton broth in screw capped tubes containing broth medium in the concentration of 1000, 500, 250, 125, 62.5 and $31.25 \mu \mathrm{g} /$ $\mathrm{mL}$. Bacterial suspensions of the test organism were prepared in sterilized Mueller-Hinton broth. $1 \mathrm{~mL}$ of the dilution was added to each sterilized screw capped tube containing $1 \mathrm{~mL}$ of sample suitably diluted in the sterilized broth medium to give a final volume of $2 \mathrm{~mL}$. A culture medium without sample (solvent DMSO) was used as a negative control. Ciprofloxacin (100-0.191 $\mu \mathrm{g} /$ $\mathrm{mL}$.) was used as positive control. Tubes were incubated aerobically at $37{ }^{\circ} \mathrm{C}$ for $18 \mathrm{~h}$ and the growth was indicated by turbidity. The lowest concentration (preventing visible growth indicated by no turbidity) was identified as the MIC and expressed in $\mu \mathrm{g} / \mathrm{mL}$. The complete absence of growth was considered as the MBC [23]. To confirm the results of $\mathrm{MBC}, 10 \mu \mathrm{L}$ of the experimental suspensions (withdrawn from the tubes with no growth) were subcultured on TSA (Tryptone Soy Agar) plates. The Plates were incubated at $37^{\circ} \mathrm{C}$ for $24 \mathrm{~h}$. It showed no bacterial growth, which was taken as the MBC. Values were recorded as $\mu \mathrm{g} / \mathrm{mL}$.

\section{Antifungal activity test}

The antifungal activity test was performed by a similar procedure as antibacterial activity test. But PDA growth medium was used instead of NA medium. Positive control (Flucanozole $100 \mu \mathrm{g} / \mathrm{mL}$ ) and essential oil containing petri dishs were incubated at $25 \pm 2{ }^{\circ} \mathrm{C}$ for $72 \mathrm{~h}$. The MICs and MBCs of the selected fungi were also done by the micro dilution method as described in the antibacterial activity test.

\section{Statistical analysis}

Statistical analysis of all data was performed by means of the Microsoft Excel 7.0 version for windows. All data are presented as mean value \pm standard deviation $(n=3)$. The values were considered significantly different at $(P<0.05)$.

\section{Results}

Proximate composition

The proximate composition of the Anethum sowa root L. is presented in Table 2. The root contained the high crude fibre, carbohydrate and ash with low
Table 2 Proximate composition of Anethum sowa L. Root

\begin{tabular}{lc}
\hline Characteristics & Percent (\%) Composition \\
\hline Moisture (On fresh weight basis) & $78.46 \pm 0.23$ \\
Dry matter (On fresh weight basis) & $21.54 \pm 0.23$ \\
Organic content & $94.71 \pm 0.12$ \\
Ash (On dry weight basis) & $5.29 \pm 0.10$ \\
Ash (On fresh weight basis) & $1.14 \pm 0.01$ \\
Acid insoluble ash & $0.32 \pm 0.02$ \\
Water soluble ash & $1.87 \pm 0.00$ \\
Nitrogen (Kjeldahl method) & $0.32 \pm 0.01$ \\
Protein & $2.01 \pm 0.07$ \\
Crude fibre & $54.09 \pm 0.50$ \\
Fatty oil (Hot extract) & $1.14 \pm 0.01$ \\
Fatty oil (Cold extract) & $0.60 \pm 0.11$ \\
Essential oil (On dry weight basis) & $0.15 \pm 0.09$ \\
Carbohydrate (Calculated by difference) & $28.53 \pm 0.30$ \\
\hline
\end{tabular}

Data are expressed as Mean \pm SD $(n=3)$

fat and essential oil. The protein content is found to be moderate and also rich in glutamic acid, glycine and lysine. The moisture content was determined on the fresh weight basis, whereas the organic content was calculated on the dried basis. On the other hand, the water soluble ash was found the higher than the acid insoluble ash.

\section{Fatty acid composition}

The cold and hot extracted fatty acids were semisolid, opaque, light golden colour with an unpleasant odour and a slightly bitter taste. The extracted fatty acids were found to be freely soluble in most of the common organic solvents. The fatty acid compositions are shown in Table 3. In all of them, 8 fatty acids were present. Amongst which, six fatty acids $(1-3,6-8)$ were found as saturated with a polyunsaturated and monounsaturated fatty acids in the cold and hot extracted part respectively. The most predominant fatty acids were palmitic acid followed by linoleic acid, behenic acid and lignoceric acid. Oleic acid was found the higher amount in hot extracted part than the cold extracted part. The nutritional quality of lipid fractions was evaluated by the different indexes (Table 3). In the present study, ratio of PUFA:SFA is 0.43:0.40 in the cold and hot extracted fatty acid respectively. In the current study, TI was found higher in cold extract than the hot extracted fatty acids. On the other hand, AI was found higher in the cold extract, but the lower value was found in hot extracted fatty acids. The standard and sample fatty acids methyl esters (FAMEs) chromatograms are shown in additional files (Additional file 1: Figure S1, Additional file 2: Figure S2 \& Additional file 3: Figure S3). 
Table 3 Fatty acid composition of Anethum sowa L. root extract (cold and hot extracts) by GC

\begin{tabular}{|c|c|c|c|c|c|c|c|}
\hline \multicolumn{2}{|c|}{ Fatty acid compounds } & \multicolumn{3}{|c|}{ Cold extract } & \multicolumn{3}{|c|}{ Hot extract } \\
\hline & & & \multirow{2}{*}{$\begin{array}{ll}\text { IA } \\
31956\end{array}$} & \multirow{2}{*}{$\begin{array}{l}\text { Relative percentage } \\
5.24\end{array}$} & \multirow{2}{*}{$\begin{array}{l}R_{t} \\
9.751\end{array}$} & \multirow{2}{*}{$\frac{1 \mathrm{~A}}{407}$} & \multirow{2}{*}{$\begin{array}{l}\text { Relative percentage } \\
0.17\end{array}$} \\
\hline 1. & ${ }^{a}$ Myristic acid $\left(C_{14: 0}\right)$ & & & & & & \\
\hline 2. & apalmitic acid $\left(\mathrm{C}_{16: 0}\right)$ & 13.33 & 205940 & 33.81 & 13.334 & 74176 & 31.58 \\
\hline 3. & ${ }^{\mathrm{a}}$ Stearic acid $\left(\mathrm{C}_{18: 0}\right)$ & 16.17 & 30015 & 4.93 & 16.176 & 9810 & 4.17 \\
\hline 4. & ${ }^{\mathrm{C}}$ Oleic acid $\left(\mathrm{C}_{18: 1}\right)$ & 15.83 & 5392 & 0.89 & 15.830 & 41976 & 17.87 \\
\hline 5. & bLinoleic acid $\left(C_{18: 2}\right)$ & 15.75 & 182845 & 30.03 & 15.754 & 55875 & 23.79 \\
\hline 6. & ${ }^{a}$ Arachidic Acid $\left(C_{20: 0}\right)$ & 18.80 & 15831 & 2.60 & 18.809 & 4541 & 1.93 \\
\hline 7. & aBehenic acid $\left(C_{22: 0}\right)$ & 21.24 & 77302 & 12.70 & 21.242 & 23580 & 10.04 \\
\hline 8. & $\begin{array}{l}\text { aLignoceric acid }\left(\mathrm{C}_{24: 0}\right) \\
\text { (Tetracosanoic acid) }\end{array}$ & 23.61 & 59715 & 9.80 & 23.612 & 24456 & 10.45 \\
\hline \multicolumn{2}{|c|}{ Total } & & 608996 & 100 & & 234821 & 100 \\
\hline \multicolumn{2}{|c|}{ aSaturated (\%) } & & & 69.08 & & & 58.34 \\
\hline \multicolumn{2}{|c|}{ boly-unsaturated (\%) } & & & 30.03 & & & 23.79 \\
\hline \multicolumn{2}{|c|}{ cMono-unsaturated (\%) } & & & 0.89 & & & 17.87 \\
\hline \multicolumn{2}{|c|}{ PUFA/SFA } & & & 0.43 & & & 0.40 \\
\hline \multicolumn{2}{|c|}{$\mathrm{Al}$} & & & 1.771 & & & 0.77 \\
\hline \multicolumn{2}{|c|}{ TI } & & & 2.84 & & & 1.72 \\
\hline
\end{tabular}

$R_{t}$ Retention time, IA Individual Area, Al Anthrogenic Index, TI Thrombogenicity Index, PUFA Poly-unsaturated fatty acids, SFA Saturated fatty acids

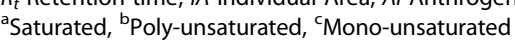

Table 4 Amino acid composition (g/100 g crude protein) of Anethum sowa root

\begin{tabular}{|c|c|c|c|c|c|c|}
\hline \multirow{2}{*}{$\begin{array}{l}\text { Name of Amino } \\
\text { Acids }\end{array}$} & \multirow{2}{*}{$\begin{array}{l}\text { Sample } \\
\text { Retention } \\
\text { Time }\end{array}$} & \multirow{2}{*}{$\begin{array}{l}\text { Standard } \\
\text { Retention } \\
\text { Time }\end{array}$} & \multirow{2}{*}{$\begin{array}{l}\text { Sample } \\
\text { Individual } \\
\text { Area }\end{array}$} & \multirow{2}{*}{$\begin{array}{l}\text { Standard } \\
\text { Individual } \\
\text { Area }\end{array}$} & \multicolumn{2}{|c|}{ Concentration } \\
\hline & & & & & $\mathrm{g} / 100 \mathrm{~g} \mathrm{DB}$ & $\mathrm{g} / 100 \mathrm{~g} \mathrm{FB}$ \\
\hline Serine $(\text { Ser })^{\mathrm{b}, \mathrm{g}}$ & 10.392 & 10.471 & 1361824 & 2701518 & 3.58 & 4.01 \\
\hline Glutamic acid $(G \mid u)^{b, d}$ & 11.212 & 11.535 & 4493784 & 1649736 & 19.37 & 21.67 \\
\hline Glycine $(\text { Gly })^{\mathrm{b}, \mathrm{g}}$ & 15.262 & 16.138 & 14738830 & 7210517 & 14.53 & 16.26 \\
\hline Alanine $(A l a)^{b, g}$ & 17.360 & 18.191 & 525832 & 1186996 & 3.15 & 3.52 \\
\hline Valine $(\text { Val })^{\mathrm{a}, \mathrm{g}}$ & 21.543 & 19.752 & 356860 & 1517660 & 1.67 & 1.87 \\
\hline Methionine (Met) $)^{\mathrm{a}, \mathrm{f}, \mathrm{g}}$ & 22.448 & 22.300 & 937009 & 1213589 & 5.49 & 6.14 \\
\hline Isoleucine $(\| l e)^{a, g}$ & 24.957 & 23.235 & 310181 & 1877608 & 1.17 & 1.31 \\
\hline Leucine (Leu) $)^{\mathrm{a}, \mathrm{g}}$ & 26.182 & 25.570 & 467152 & 1648575 & 2.01 & 2.25 \\
\hline Tyrosine $(T y r)^{b, c, g}$ & 27.415 & 26.796 & 390655 & 1877669 & 1.47 & 1.65 \\
\hline Histidine $(H i s)^{a, e}$ & 28.371 & 28.295 & 7778337 & 8098543 & 6.82 & 7.64 \\
\hline Lysine (Lys) ${ }^{a, e}$ & 32.084 & 32.045 & 3868261 & 1609813 & 17.08 & 19.12 \\
\hline Arginine $(\operatorname{Arg})^{a, e}$ & 33.663 & 33.693 & 473612 & 2266037 & 1.48 & 1.66 \\
\hline \multicolumn{2}{|l|}{ Total } & & 35702337 & 32858261 & 77.87 & 87.14 \\
\hline \multicolumn{3}{|l|}{${ }^{\mathrm{a} E s s e n t i a l ~ a m i n o ~ a c i d s ~}$} & & & 35.75 & 40.00 \\
\hline \multicolumn{3}{|c|}{${ }^{\mathrm{b}}$ Non Essen. Amino Acids } & & & 42.12 & 47.13 \\
\hline \multicolumn{3}{|l|}{ 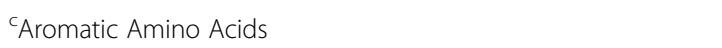 } & & & 1.47 & 1.65 \\
\hline \multicolumn{3}{|l|}{ dAcidic Amino Acids } & & & 19.37 & 21.67 \\
\hline \multicolumn{3}{|l|}{${ }^{\mathrm{e}}$ Basic Amino Acids } & & & 25.40 & 28.42 \\
\hline \multicolumn{3}{|l|}{ fSulphur Amino Acids } & & & 5.49 & 6.14 \\
\hline \multicolumn{3}{|l|}{${ }^{9}$ Neutral Amino Acids } & & & 33.10 & 37.04 \\
\hline \multicolumn{5}{|c|}{$\%$ of essential amino acid in total amino acid } & 45.90 & 45.90 \\
\hline
\end{tabular}

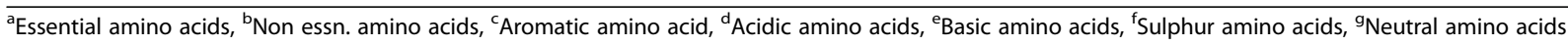


Table 5 Essential elemental composition $(\mu \mathrm{g} / \mathrm{kg})$ of Anethum sowa L. root

\begin{tabular}{|c|c|c|c|c|c|}
\hline \multirow[t]{2}{*}{ Elements } & \multicolumn{3}{|c|}{ Anethum sowa L. Root } & \multirow{2}{*}{$\begin{array}{l}\text { RSD } \\
\%\end{array}$} & \multirow{2}{*}{$\begin{array}{l}\text { Instrumental } \\
\text { Method }\end{array}$} \\
\hline & Solution Conc. & DWB (ppb) & FWB (ppb) & & \\
\hline $\mathrm{Be}$ & 0.7977 & 2.09 & 1.90 & 2.84 & ICP-MS \\
\hline $\mathrm{Ag}$ & 8.039 & 21.10 & 19.23 & 0.97 & ICP-MS \\
\hline Cs & 8.2059 & 21.53 & 19.63 & 1.18 & ICP-MS \\
\hline $\mathrm{Bi}$ & 8.2364 & 21.61 & 19.70 & 1.03 & ICP-MS \\
\hline Ga & 9.6419 & 25.30 & 23.07 & 1.18 & ICP-MS \\
\hline Co & 26.1657 & 68.67 & 62.61 & 1.36 & ICP-MS \\
\hline Li & 121.093 & 317.84 & 289.76 & 0.08 & ICP-MS \\
\hline Se & 348.141 & 913.79 & 833.06 & 2.11 & ICP-MS \\
\hline $\mathrm{Ni}$ & 452.343 & 1187.30 & 1082.40 & 0.76 & ICP-MS \\
\hline
\end{tabular}

\section{Amino acid composition}

The amino acid profile of Anethum sowa L. root was calculated in $\mathrm{g} / 100 \mathrm{~g}$ protein on the dry weight basis and the results are shown in Table 4. In the present study, twelve amino acids were identified with an injection time of $35 \mathrm{~min}$. Glutamic acid, lysine and glycine were found the most predominant amino acids in the analysed sample. The non-essential amino acid contained the higher amino acid content in comparison to the essential and neutral amino acids. Lysine was the highest essential amino acid out of seven essential amino acids. The total basic amino acid is greater than that of total acidic amino acid. The percentage of essential amino acids of the total amino acid was 45.90 whereas, total amount of sulphur containing amino acid was $5.49 \mathrm{~g} /$ $100 \mathrm{~g}$ protein. On the other hand, only tyrosine was found as an aromatic amino acid in the current study. The standard and sample amino acids chromatograms are shown in additional files (Additional file 4: Figure S4 \& Additional file 5: Figure S5),

\section{Elemental composition}

The results of the elemental compositions of Anethum sowa L. root are shown in Table 5, Table 6 and Table 7. A total of 21 elements were analyzed which are designated as essential and non-essential elements. The relative standard deviation (RSD\%) values for the studied elements were found to be $\leq 5 \%$. The concentrations of the elements are calculated on fresh (FB) and dry weight basis $(\mathrm{DB})$ within the significance level $(\mathrm{p} \leq 0.05)$. In the current experiment, $\mathrm{Ca}, \mathrm{Mg}, \mathrm{K}, \mathrm{Na}, \mathrm{Fe}$ and $\mathrm{Al}$ were detected as rich essential elements followed by $\mathrm{Ni}$, Se and $\mathrm{Li}$ on the dry weight basis (DWB). Hg was detected the highest level of the analyzed toxic elements followed by $\mathrm{As}$ and $\mathrm{Cd}$. On the other hand, $\mathrm{Cr}$ and $\mathrm{Pb}$ were not found in the current experiment.
Table 6 Essential elemental composition $(\mathrm{mg} / \mathrm{kg})$ of Anethum sowa L. root

\begin{tabular}{|c|c|c|c|c|c|}
\hline \multirow[t]{2}{*}{ Elements } & \multicolumn{3}{|c|}{ Anethum sowa L. Root } & \multirow{2}{*}{$\begin{array}{l}\text { RSD } \\
\%\end{array}$} & \multirow{2}{*}{$\begin{array}{l}\text { Instrumental } \\
\text { Method }\end{array}$} \\
\hline & Solution Conc. & DWB (ppm) & FWB (ppm) & & \\
\hline $\mathrm{Mn}$ & 6.56 & 17.21 & 15.69 & 0.1 & AAS \\
\hline $\mathrm{Al}$ & 53.08 & 139.32 & 127.01 & 0.1 & AAS \\
\hline $\mathrm{Fe}$ & 78.82 & 206.88 & 188.60 & 0.1 & AAS \\
\hline $\mathrm{Na}$ & 110 & 288.72 & 263.21 & 0.1 & $\mathrm{FP}$ \\
\hline K & 490 & 1286.15 & 1172.51 & 0.1 & FP \\
\hline $\mathrm{Mg}$ & 2903.21 & 7620.33 & 6947.08 & 0.1 & AAS \\
\hline $\mathrm{Ca}$ & 8991.18 & 23600.01 & 21514.95 & 0.1 & AAS \\
\hline
\end{tabular}

RSD Relative Standard Deviation, DWB Dry Weight Basis, FWB Fresh Weight Basis

\section{Thermal analysis}

The thermal analysis data are shown in Table 8. The thermal decomposition of the root powder comes through three common stages. In the first stage, broad and shallow endothermic DTA curve observed at $81.7^{\circ} \mathrm{C}$. In the second stage of decomposition is occurred on the DTA curve at $328.3{ }^{\circ} \mathrm{C}$. A mass loss with a rate of $0.151 \mathrm{mg} / \mathrm{min}$ (at $75.9{ }^{\circ} \mathrm{C}$ ) by heating the sample up to $0.373 \mathrm{mg} / \mathrm{min}$ (at $257^{\circ} \mathrm{C}$ ) is mentioned by the DTG curve. The highest mass loss was indicated in the second stage at $92.7 \%$ of TG at $275.7{ }^{\circ} \mathrm{C}$ and $1.167 \mathrm{mg} / \mathrm{min}$ at $328.3^{\circ} \mathrm{C}$ of DTG curve. At this stage, pyrolysis was obtained when the temperature increased from 250 to $380{ }^{\circ} \mathrm{C}$. Lignin decomposition was occurring in the range of $380-500{ }^{\circ} \mathrm{C}$. The residual carbonaceous material in the previous steps was burnt at from 275 to $550{ }^{\circ} \mathrm{C}$ presenting an endothermic TG curve. The charred residue was produced by the destruction of low molecular compounds in the third and final stage of decomposition and yielded an ash residue. Finally, no mass loss was detected when the temperature increased from $550{ }^{\circ} \mathrm{C}$ to $800{ }^{\circ} \mathrm{C}$. Representative thermo-gravimetric spectrum of the root is shown in additional file (Additional file 6: Figure S6).

\section{Chemical composition of the essential oil}

The essential oil of $A$. sowa was colourless with a characteristic odour. A total of 24 constituents were identified and quantified in the essential oil and its water

Table 7 Non-essential elemental composition $(\mu \mathrm{g} / \mathrm{kg})$ of Anethum sowa L. root

\begin{tabular}{|c|c|c|c|c|c|}
\hline \multirow[t]{2}{*}{ Elements } & \multicolumn{3}{|c|}{ Anethum sowa L. Root } & \multirow{2}{*}{$\begin{array}{l}\text { RSD } \\
\%\end{array}$} & \multirow{2}{*}{$\begin{array}{l}\text { Instrumental } \\
\text { Method }\end{array}$} \\
\hline & Solution Conc. & DWB (ppb) & FWB (ppb) & & \\
\hline $\mathrm{Cr}$ & ND & ND & ND & ND & ICP-MS \\
\hline $\mathrm{Pb}$ & ND & ND & ND & ND & ICP-MS \\
\hline $\mathrm{Cd}$ & 14.7679 & 38.76 & 35.33 & 1.54 & ICP-MS \\
\hline As & 16.5858 & 43.53 & 39.68 & 2.88 & ICP-MS \\
\hline $\mathrm{Hg}$ & 48.45 & 965.52 & 880.22 & 0.3 & AAS \\
\hline
\end{tabular}

RSD Relative Standard Deviation, DWB Dry Weight Basis, FWB Fresh Weight Basis 
Table 8 Results of TG and DTG (mass loss and temperature) of Anethum sowa L. root powder

\begin{tabular}{lcllll}
\hline Events & TG & & & DTG \\
\cline { 2 - 3 } & Mass loss (\%) & $\begin{array}{l}\mathrm{T}_{\text {onset }}{ }^{-} \mathrm{T}_{\text {offset }} \\
\left({ }^{\mathrm{C}} \mathrm{C}\right)\end{array}$ & $\begin{array}{l}\text { Mass loss } \\
(\mathrm{mg} / \mathrm{min})\end{array}$ & $\begin{array}{l}\mathrm{T}_{\text {onset }}{ }^{-} \mathrm{T}_{\text {offset }} \\
\left({ }^{\circ} \mathrm{C}\right)\end{array}$ \\
\hline First step & 92.7 & $\mathrm{~T}_{\text {room }}-275$ & 0.151 & $\mathrm{~T}_{\text {room }}-75.9$ \\
Second step & 53.3 & $276-327$ & 0.373 & $76-257$ \\
Third step & 29.6 & $328-358$ & & 1.167 & $258-328$ \\
\% Residue & 25.9 & $359-550$ & - & - \\
\hline
\end{tabular}

Table 9 Compound composition (\% w/w) in the essential oil and water extract part of Anethum sowa L. root

\begin{tabular}{|c|c|c|c|c|c|c|}
\hline \multirow{2}{*}{$\begin{array}{l}\text { SL } \\
\text { No. }\end{array}$} & \multirow{2}{*}{$\begin{array}{l}\text { RI } \\
\text { Index }\end{array}$} & \multirow[t]{2}{*}{ Name of Compounds } & \multicolumn{2}{|c|}{$\underline{\text { Essential oil }}$} & \multicolumn{2}{|c|}{ Water extract part } \\
\hline & & & $\mathrm{R}_{t}$ & $\begin{array}{l}\text { Conc. } \\
(\%)\end{array}$ & $\mathrm{R}_{t}$ & $\begin{array}{l}\text { Conc. } \\
(\%)\end{array}$ \\
\hline 1 & 349 & Ethylene oxide & - & ND & 16.249 & 0.294 \\
\hline 2 & 653 & Glycidol & - & ND & 7.893 & 0.264 \\
\hline 3 & 707 & n-Pentanal & 9.441 & 0.053 & - & ND \\
\hline 4 & 721 & Isobutyl acetate & - & ND & 3.769 & 3.733 \\
\hline 5 & 766 & $\beta$-Butyrolactone & - & ND & 3.228 & 5.131 \\
\hline 6 & 767 & $\begin{array}{l}\text { 2,3,3-Trimethyl } \\
\text { hexane }\end{array}$ & 3.677 & 0.068 & - & ND \\
\hline 7 & 794 & Toluene & 3.606 & 2.40 & 3.635 & 3.327 \\
\hline 8 & 806 & n-Hexanal & 4.165 & 0.166 & - & ND \\
\hline 9 & 831 & Furfural & - & ND & 4.800 & 0.48 \\
\hline 10 & 905 & n-Heptanal & 6.021 & 0.148 & - & ND \\
\hline 11 & 907 & p-Xylene & 5.422 & 0.895 & - & ND \\
\hline 12 & 1005 & n-Octanal & 7.885 & 0.238 & - & ND \\
\hline 13 & 1081 & 2-Phenyl-acetaldehyde & 8.653 & 0.106 & - & ND \\
\hline 14 & 1197 & p-Cymen-8-ol & 11.026 & 0.878 & 11.027 & 1.109 \\
\hline 15 & 1224 & $\begin{array}{l}\text { 4-Thujen-2-alpha-yl } \\
\text { acetate }\end{array}$ & 11.323 & 0.082 & - & ND \\
\hline 16. & 1260 & Cyclohexane, 3-hexyl & - & ND & 17.730 & 0.50 \\
\hline 17. & 1294 & 2-Aminoundecane & 15.164 & 0.244 & - & ND \\
\hline 18. & 1304 & m-Diaminobenzene & 18.758 & 10.446 & 18.755 & 8.778 \\
\hline 19. & 1334 & (+/-)-Norephedrine & 18.440 & 0.103 & - & ND \\
\hline 20. & 1421 & Thymol acetate & 12.773 & 0.878 & - & ND \\
\hline 21 & 1516 & Myristicin & 15.900 & 0.868 & 15.900 & 0.716 \\
\hline 22 & 1550 & Elemicin & 16.251 & 0.426 & - & ND \\
\hline 23 & 1705 & Apiol & 17.897 & 81.99 & 17.887 & 74.779 \\
\hline 24 & 2187 & $\begin{array}{l}\text { 3,4-Dimethyl-benzoic } \\
\text { acid 4-tert-bytyl-phenyl } \\
\text { ester }\end{array}$ & - & ND & 17.614 & 0.881 \\
\hline Tota & & & & 100 & & 100 \\
\hline
\end{tabular}

RI Index Retention Index (compounds rearrangement with their retention index), $R_{t}$ Retention time ND Not Detected extract part by GC and GC-MS and the results are shown in Tables 9 and 10 and Figs. 1 and 2. In this assay, 17 compounds from essential oil and 13 compounds from water extracted part were identified, which accounted for $100 \%$ of the total amount. Phenylpropanoids were contributed the major compounds of the essential oil and water extracted portion. Other predominant compound groups like lactone and ester were found in the water extracted part. Hydrocarbons were boiled out and produced an emulsion in the water extracted part which contributed $3.827 \%$ in the water extract part and $3.363 \%$ in the oily part. Apiol and $\mathrm{m}$-diaminobenzene were the predominant components of the essential oil. In the case of water extracted part, apiol was found the highest component followed by $\mathrm{m}$-diaminobenzene, $\beta$-butyrolactone and isobutylactone.

\section{Antioxidant activity on DPPH radical}

The DPPH radical scavenging activity of the essential oil and synthetic standard ASA and BHT are shown in Table 11 and Fig. 3. The $\mathrm{IC}_{50}$ value of the essential oil was found to be $6.13 \pm 0.03 \mathrm{mg} / \mathrm{mL}$ with the highest inhibition of $93.43 \mathrm{mg} / \mathrm{mL}$. However, this value is much weaker than those of standard BHT and ASA.

\section{Brine shrimp cytotoxicity assay}

The results of brine shrimp cytotoxicity lethality test of the essential oil were tabulated by the Finney probit method [24] and shown in Table 12 and Fig. 4. The essential oil was found to be toxic by comparing with standard anticancer drug vincristine sulphate.

Antimicrobial activity of Anethum sowa L. root essential oil The results of antimicrobial activity of Anethum sowa L. essential oils are shown in Tables 13, 14 and Figs. 5 \& 6.

Table 10 Concentration of different compound classes of Anethum sowa L. root essential oil and water extractive part

\begin{tabular}{llll}
\hline SI No. & Compound classes & Essential oil part (\%) & Water extract part (\%) \\
\hline 1. & Hydrocarbon & 3.363 & 3.827 \\
2. & Aldehyde & 0.658 & ND \\
3. & Alcohol & ND & 0.264 \\
4. & Lactone & ND & 5.131 \\
5. & Ester & 0.96 & 4.614 \\
6. & Oxide & ND & 0.294 \\
7. & Hemiterpenoid & 0.053 & 0.48 \\
& Aldehyde & & \\
8. & Monoterpenoid & 0.878 & 1.109 \\
& Alcohol & & \\
9. & Phenylpropanoid & 83.284 & 75.495 \\
10. & Others & 10.793 & 8.778 \\
Total & & 100 & 100 \\
\hline
\end{tabular}




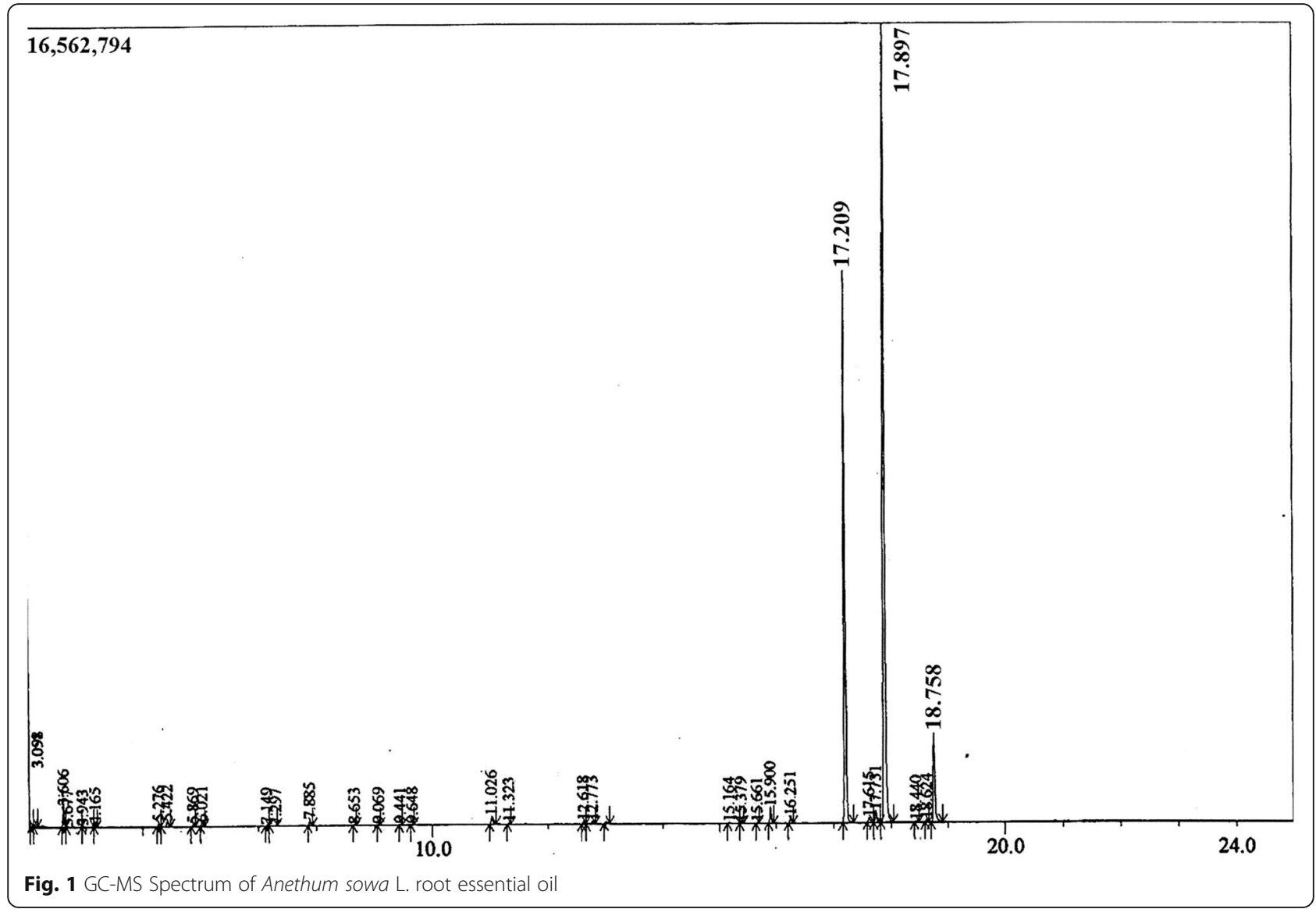

The oil inhibited the growth of bacterial strains producing a zone diameter of inhibition from 3 to $16 \mathrm{~mm}$, depending on the susceptibility of the tested bacteria and the different dosage level. The highest inhibition of zone was found against Escherichia coli 2799 followed by Pseudomonas aeruginosa and their effects are also higher than standard antibiotic tetracycline and lower than ciprofloxacin. On the other hand, Enterococcus faecalis showed the high resistant to the essential oil. However, other Gram-positive and Gram-negative bacteria exhibited moderate to weak activities than the standard antibiotics. The MICs of the essential oils were within concentration ranges from 62.5 to $250 \mu \mathrm{g} / \mathrm{mL}$ and the respective MBCs were from 125 to $500 \mu \mathrm{g} / \mathrm{mL}$. The organism like E. coli 12079 and S. typhi were less susceptible to the oil with MICs value of $250 \mu \mathrm{g} / \mathrm{mL}$ respectively. The MIC and MBC values of standard ciprofloxacin were varied between $0.19-6.25 \mu \mathrm{g} / \mathrm{mL}$ and $3.125-100 \mu \mathrm{g} / \mathrm{mL}$ respectively.

\section{Antifungal activity of Anethum sowa L. root essential oil} The antifungal activity of the essential oil shown in Table 15. The highest zone of inhibition was shown against $A$. niger at $800 \mu \mathrm{g} /$ well but there was no observable zone of inhibition was found in $T$. $s p$. On the other hand, no zone was observed at $400 \mu \mathrm{g} /$ well dose level. The standard drug fluconazole was highly sensitive to all the fungi at the dose of $100 \mu \mathrm{g} /$ well. In the MICs and MBCs experiments, the essential oil showed the highest inhibition i.e. the lowest MICs and MBCs. In the case of fluconazole, it completely inhibited the entire test fungi.

\section{Discussion}

The data on the proximate composition of Anethum sowa L. root has been reported for the first time. The ash content is found very high in the current study, indicating the high quality of essential minerals which is comparable with an acceptable ash range of legumes (2.4-5.0\%) [25]. Acid insoluble ash is an indicator of silicate impurity and water soluble ash is indicated the highly soluble mineral contents in the root sample.

The oil from a single source has not been found to be suitable for consumption and medicinal preparation because of their different chemical compositions. So, the necessity for searching of new oil source is a major research interest in the present day. Our previously published data on the fatty acid composition of Anethum sowa seed and flower part [26, 27] revealed that oleic acid was the highest in seed (87.10\%) and flower (51.93\%) part than our current study. Moreover, palmitic 


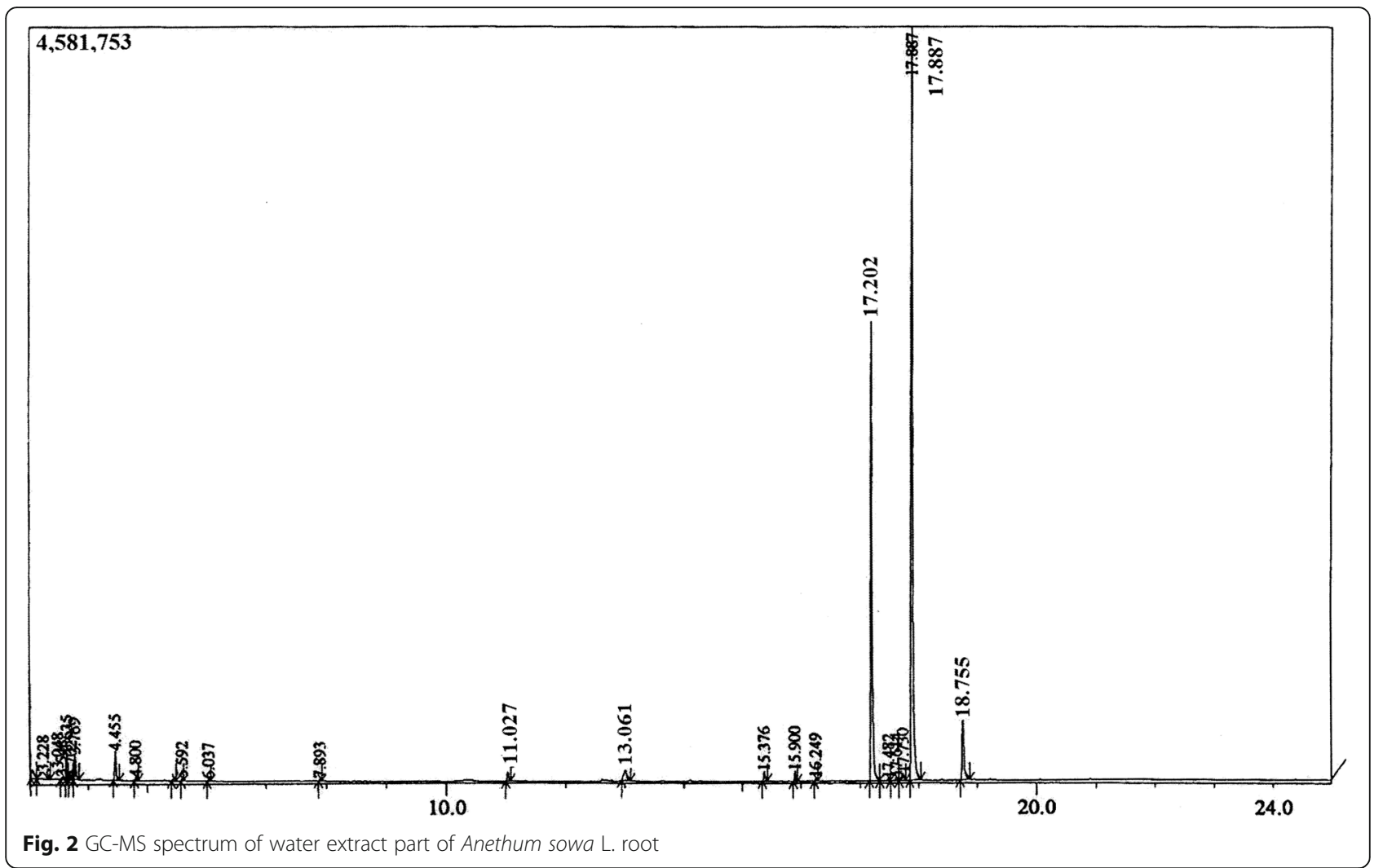

acid content is almost similar to the flower fatty acid (30.74\%) but it is found higher than the seed (4.27\%) fatty acid. Linoleic acid is one of the essential polyunsaturated fatty acids which prevents cardiovascular diseases and its derivatives serve as structural components of the plasma membrane [28]. It also has a beneficial effect on blood lipids, lowering blood pressure and serum cholesterol. The nutritional value of linoleic acid is due to its metabolism at the tissue levels, which produced the hormone-like prostaglandins [29]. It was found the second highest fatty acid in the present study. The saturated fatty acids like lauric, myristic and palmitic acid have been established as the most important of the dietary risk factors and resulted in a high level of total blood cholesterol [30]. Diets with a PUFA:SFA ratio was found the below of 0.45 , which considered inadequate because of their potential to increase blood cholesterol levels [31]. On the other hand, higher SFA stimulates the de nova synthesis of cholesterol in the body. Thus, it indicates that these are not a good source of fatty acids for

Table 11 Antioxidant activity of Anethum sowa L. root essential oil and standards

\begin{tabular}{|c|c|c|c|c|c|c|}
\hline \multicolumn{3}{|l|}{ Essential oil } & \multicolumn{4}{|l|}{ Standard Antioxidants } \\
\hline $\begin{array}{l}\text { Dose Concentration } \\
(\mathrm{mg} / \mathrm{mL})\end{array}$ & Log Dose & $\begin{array}{l}\text { Average percent of } \\
\text { Inhibition } \pm \text { SD }\end{array}$ & $\begin{array}{l}\text { Dose Concentration } \\
(\mu \mathrm{g} / \mathrm{mL})\end{array}$ & Log Dose & $\begin{array}{l}\text { Average percent of } \\
\text { Inhibition } \pm \text { SD of } \mathrm{BHT}\end{array}$ & $\begin{array}{l}\text { Average percent of } \\
\text { Inhibition } \pm \text { SD of ASA }\end{array}$ \\
\hline 46.5 & 1.66 & $93.43 \pm 0.24$ & 200 & 2.301 & $93.02 \pm 0.50$ & $99.05 \pm 0.21$ \\
\hline 23.25 & 1.36 & $89.56 \pm 0.22$ & 100 & 2 & $91.98 \pm 0.19$ & $98.35 \pm 0.17$ \\
\hline 11.625 & 1.06 & $84.17 \pm 0.25$ & 50 & 1.698 & $85.51 \pm 0.76$ & $90.71 \pm 0.60$ \\
\hline 5.8125 & 0.764 & $64.68 \pm 0.21$ & 25 & 1.397 & $69.54 \pm 0.60$ & $85.31 \pm 0.60$ \\
\hline 2.90625 & 0.463 & $41.25 \pm 0.12$ & 12.5 & 1.096 & $55.87 \pm 0.82$ & $79.79 \pm 0.18$ \\
\hline 1.453125 & 0.162 & $32.41 \pm 0.31$ & 6.25 & 0.795 & $29.69 \pm 0.97$ & $69.67 \pm 0.68$ \\
\hline 0.72656 & -0.138 & $19.71 \pm 0.40$ & 3.125 & 0.494 & $25.63 \pm 0.51$ & $37.26 \pm 1.12$ \\
\hline 0.36328 & -0.439 & $17.18 \pm 0.05$ & 1.5625 & 0.193 & $9.05 \pm 0.51$ & $27.02 \pm 1.19$ \\
\hline \multicolumn{5}{|c|}{ Average $I C_{50}$ value $=3.07 \pm 0.01 \mathrm{mg} / \mathrm{mL}$} & $\mathrm{IC}_{50}$ value $=11.84 \pm 0.29 \mu \mathrm{g} / \mathrm{mL}$ & $\mathrm{IC}_{50}$ value $=3.74 \pm 0.05 \mu \mathrm{g} / \mathrm{mL}$ \\
\hline
\end{tabular}




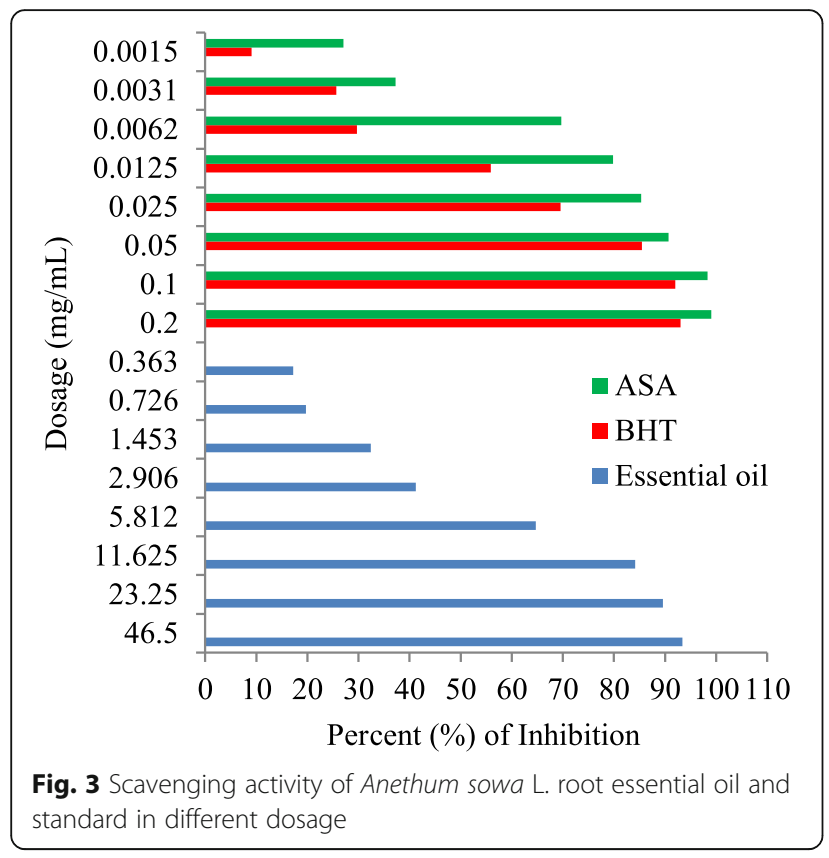

human health. Moreover, TI was found higher than 1 in cold and hot extracted fatty acids while AI was found higher than 1 in cold extracted fatty acid, but the lower value was found in hot extracted fatty acids. The AI and TI indexes have considered as cardiovascular disease risk factors. Thus, these indices must be kept low. It was reported that lower AI leads to a decrease in the total cholesterol and the LDL-cholesterol in human blood plasma [32]. To the best our knowledge, this is the first report regarding the fatty acids of $A$. sowa root. This investigation has given us valuable information about the structure of the fatty acids and also indicated that these oils cannot be considered as functional ingredients of human diet but it may be a valuable source for the cosmetic or industrial application.
Primarily, the nutritive value of a protein depends on the capacity to satisfy the needs for nitrogen and essential amino acid. It is indicated that the $A$. sowa $\mathrm{L}$. root protein is probably basic in nature. There is a dearth of information regarding the amino acid profile of the Anethum sowa L. root sample to the best our knowledge. Lisiewska (2004) [33] reported that leaves of Anethum graveolens L. contained rich in essential amino acid than the whole plant where leucine (10.10 for the whole plant and 9.62 for leaves of $g / 100 \mathrm{~g}$ protein) was the highest essential amino acid. Some amino acids like tryptophan, asparagines and glutamine were destroyed by acid hydrolysis method and therefore these acids were not determined. Cystein was not determined because of the rapid oxidation of this compound to form cysteic acid. The total sulphur containing amino acid $(5.49 \mathrm{~g} /$ $100 \mathrm{~g}$ protein) was close to having the recommended protein value $(5.8 \mathrm{~g} / 100 \mathrm{~g})$ for infants [34]. This value was well above the $39 \%$, considered to be adequate for ideal protein for infant, $26 \mathrm{~g} / 100 \mathrm{~g}$ protein for children and $11 \mathrm{~g} / 100 \mathrm{~g}$ protein for adult [34]. The storage of protein (i.e. amino acids) in the different parts of the plant is readily used for germination and seedling growth [35]. The proteins are considered for its essential amino acid profile due to the inability of the human body to synthesize them. The amino acid profile of the studied root sample suggests that its protein is beneficial for human health.

The concentration of elements is not uniformly distributed throughout the plant. In general, the roots contain the highest level of elements followed by stems, leaves, flowers, buds and fruits of the different maturity stages. Nevertheless, uptake of elements by a plant is influenced by various factors, including the type of plant, nature of the soil, climate and agricultural practices [36]. In the current study, the different elemental concentrations were varied due to the above factors. A. sowa $\mathrm{L}$.

Table 12 Effect of vincristine sulphate and essential oil of Anethum sowa L root on brine shrimp cytotoxicity assay

\begin{tabular}{|c|c|c|c|c|c|c|c|}
\hline \multirow{2}{*}{$\begin{array}{l}\text { Dose } \\
(\mu \mathrm{g} / \mathrm{mL})\end{array}$} & \multirow{2}{*}{$\begin{array}{l}\text { Log Dose } \\
(\mu \mathrm{g} / \mathrm{mL})\end{array}$} & \multicolumn{2}{|c|}{$\%$ of mortality } & \multicolumn{2}{|l|}{ Probit } & \multicolumn{2}{|c|}{$\mathrm{LC}_{50}(\mu \mathrm{g} / \mathrm{mL})$} \\
\hline & & $\begin{array}{l}\text { Vincristine } \\
\text { sulphate }\end{array}$ & Root essential oil & $\begin{array}{l}\text { Vincristine } \\
\text { sulphate }\end{array}$ & Root essential oil & $\begin{array}{l}\text { Vincristine } \\
\text { sulphate }\end{array}$ & Root essential oil \\
\hline 10 & 1 & 100 & 100 & 7.0959 & 6.723 & & \\
\hline 5 & 0.699 & 90 & 80 & 6.2802 & 5.8408 & & \\
\hline 2.5 & 0.3979 & 80 & 60 & 5.8413 & 5.241 & & \\
\hline 1.25 & 0.0969 & 60 & 50 & 5.2402 & 4.9977 & & \\
\hline 0.625 & -0.2041 & 60 & 40 & 4.9992 & 4.7482 & 0.48 & 0.81 \\
\hline 0.3125 & -0.5051 & 40 & 30 & 4.7467 & 4.4782 & & \\
\hline 0.156 & -0.8069 & 30 & 20 & 4.4774 & 4.1638 & & \\
\hline 0.078 & -1.1079 & 20 & 20 & 4.1665 & 4.1753 & & \\
\hline 0.039 & -1.4089 & 10 & 10 & 3.7206 & 3.7198 & & \\
\hline 0.0195 & -1.71 & 0 & 10 & 0 & 3.8288 & & \\
\hline
\end{tabular}




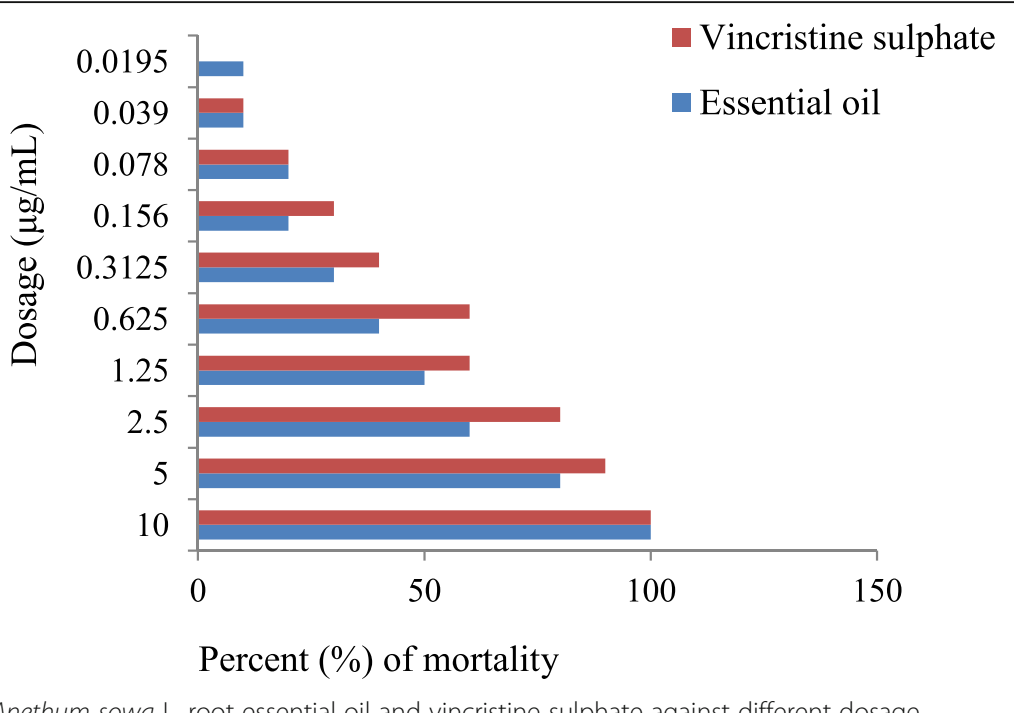

Fig. 4 Cytotoxic activity of Anethum sowa L. root essential oil and vincristine sulphate against different dosage

root accumulated a significant amount of minerals in Bangladeshi geo-environmental condition. The results are also compared with the reported [8] data of Anethum graveolens L. root where K (38,500 ppm) had the highest value, $\mathrm{Ca}(12,200 \mathrm{ppm})$ and $\mathrm{Mg}(6700 \mathrm{ppm})$ had the lowest values than our current study. The elements, especially $\mathrm{Ca}, \mathrm{Mg}, \mathrm{K}, \mathrm{Na}, \mathrm{Fe}$ and $\mathrm{Al}$ play a significant role in human metabolism and the life processes. The rich amount of $\mathrm{Ca}$ is important because of its role in bones, teeth, muscle system and heart functions [37]. $\mathrm{Mg}$ has been particularly shown to play a significant role as a regulatory cation in direct and indirect traumatic brain injury [38]. Another report on $\mathrm{Mg}$, it also helps in preventing some heart disorders and high blood pressure [39]. Recently, it has been reported that trace amounts of $\mathrm{Rb}$ and $\mathrm{Cs}$ help in the breakdown of starch to glucose [36]. Cs was present in the trace amount (21.53 ppb) in the present study. Se has anti-oxidising function and it is essential for providing the organism with triiodothyroxine produced from thyroxine [40]. It contributes to the maintenance of cellular antioxidative balance when taken up at the recommended dietary allowance of 50$100 \mu \mathrm{g} /$ day and tolerable upper intake limit is $400 \mu \mathrm{g} /$ day [41]. The high dosage of selenate has been shown to normalize hyperglycemia [36]. Li is another element with beneficial pharmacological properties which effectively used in the treatment of manic depressive disorders [42]. The result also showed that many of these elements have vital importance in human metabolism for growth, developments and also prevention and healing of diseases. The non-essential or toxic elemental contents in spice and medicinal plants are attracting attention to the scientist and also the food chemist due to its adverse effect on the human body in respect of medicinal and food preparation. The permissible limits of $\mathrm{Hg}$ and As are 1 and $10 \mathrm{mg} / \mathrm{kg}$ in foodstuff respectively [43]. The

Table 13 Anti-bacterial activity (Zone of Inhibition) of Anethum sowa L. root essential oil by diffusion method

\begin{tabular}{|c|c|c|c|c|c|c|}
\hline \multirow[t]{2}{*}{ Test organisms } & & \multicolumn{5}{|c|}{ Zone of Inhibition in mm } \\
\hline & & $400 \mu \mathrm{g} / \mathrm{well}$ & $600 \mu \mathrm{g} / \mathrm{well}$ & 800 mg/well & $\mathrm{CP}$ & TE \\
\hline \multirow[t]{4}{*}{ Gram-positive bacteria } & Bacillus subtilis & $\mathrm{nz}$ & 4 & 7 & 27 & 24 \\
\hline & Bacillus cereus & 5 & 7 & 8 & 29 & 21 \\
\hline & Staphylococcus aureus & $n z$ & 3 & 7 & 25 & 26 \\
\hline & Enterococcus faecalis & $\mathrm{nz}$ & $\mathrm{nz}$ & $\mathrm{nz}$ & 20 & 16 \\
\hline \multirow[t]{6}{*}{ Gram -negative bacteria } & Escherichia coli 12079 & $\mathrm{nz}$ & 4 & 7 & 25 & 9 \\
\hline & Escherichia coli 2799 & 11 & 13 & 16 & 23 & 11 \\
\hline & Pseudomonas aeruginosa & 8 & 9 & 11 & 29 & 16 \\
\hline & Salmonella enteritidis 1375 & $n z$ & $\mathrm{nz}$ & 5 & 39 & 23 \\
\hline & Salmonella typhi & $\mathrm{nz}$ & 5 & 9 & 35 & 25 \\
\hline & Acetobacter aceti & $\mathrm{nz}$ & $\mathrm{nz}$ & 3 & 28 & 23 \\
\hline
\end{tabular}

CP Standard Ciprofloxacin $(5 \mu \mathrm{g} / \mathrm{disc})$, TE Standard Tetracycline $(30 \mu \mathrm{g} / \mathrm{disc})$ 
Table 14 Minimum inhibitory concentration (MIC) and Minimum bactericidal concentration (MBC) of Anethum sowa L. root essential oil and standard ciprofloxacin

\begin{tabular}{|c|c|c|c|c|c|}
\hline \multirow[t]{2}{*}{ Test organisms } & & \multicolumn{2}{|l|}{ Essential Oil } & \multicolumn{2}{|l|}{ Std. CP } \\
\hline & & $\mathrm{MIC}(\mu \mathrm{g} / \mathrm{mL})$ & $\mathrm{MBC}(\mu \mathrm{g} / \mathrm{mL})$ & $\mathrm{MIC}(\mu \mathrm{g} / \mathrm{mL})$ & $\mathrm{MBC}(\mu \mathrm{g} / \mathrm{mL})$ \\
\hline \multirow[t]{4}{*}{ Gram-positive bacteria } & Bacillus subtilis & 125 & 250 & 1.55 & 12.5 \\
\hline & Bacillus cereus & 125 & 500 & 3.125 & 25 \\
\hline & Staphylococcus aureus & 125 & 250 & 6.25 & 50 \\
\hline & Enterococcus faecalis & 62.5 & 125 & 0.37 & 100 \\
\hline \multirow[t]{6}{*}{ Gram -negative bacteria } & Escherichia coli 12079 & 250 & 500 & 0.75 & 50 \\
\hline & Escherichia coli 2799 & 62.5 & 125 & 0.37 & 6.25 \\
\hline & Pseudomonas aeruginosa, & 62.5 & 125 & 3.125 & 25 \\
\hline & Salmonella enteritidis 1375 & 62.5 & 250 & 0.37 & 6.25 \\
\hline & Salmonella typhi & 250 & 500 & 0.19 & 3.125 \\
\hline & Acetobacter aceti & 62.5 & 500 & 0.37 & 50 \\
\hline
\end{tabular}

Std. CP Standard Ciprofloxacin

maximum prescribed limit of $\mathrm{Cd}$ is $0.3 \mathrm{mg} / \mathrm{kg}$ for herbal medicines and its product while the dietary intake limit is $10.3 \mathrm{mg} / \mathrm{kg}$ as per who recommendation [44]. Moreover, the toxic elements were found below the prescribed limits in the present experiment. Nonetheless, excessive intake can cause poisoning in the human body. Hg poisoning can result in damage to the brain, kidney, lungs including acrodynia (pink disease), Hunter-Russell syndrome and Minamata disease [45]. The acute sign of As poisoning includes fever, anorexia, hepatomegaly, cardiac arrhythmia, transient encephalopathy and irritation of the gastrointestinal tract [46]. Cd intoxication can lead to kidney, bone and pulmonary damages [47]. $\mathrm{Pb}$ and $\mathrm{Cd}$ cause both acute and chronic poisoning, adverse effects on the kidney, liver, heart, vascular and immune

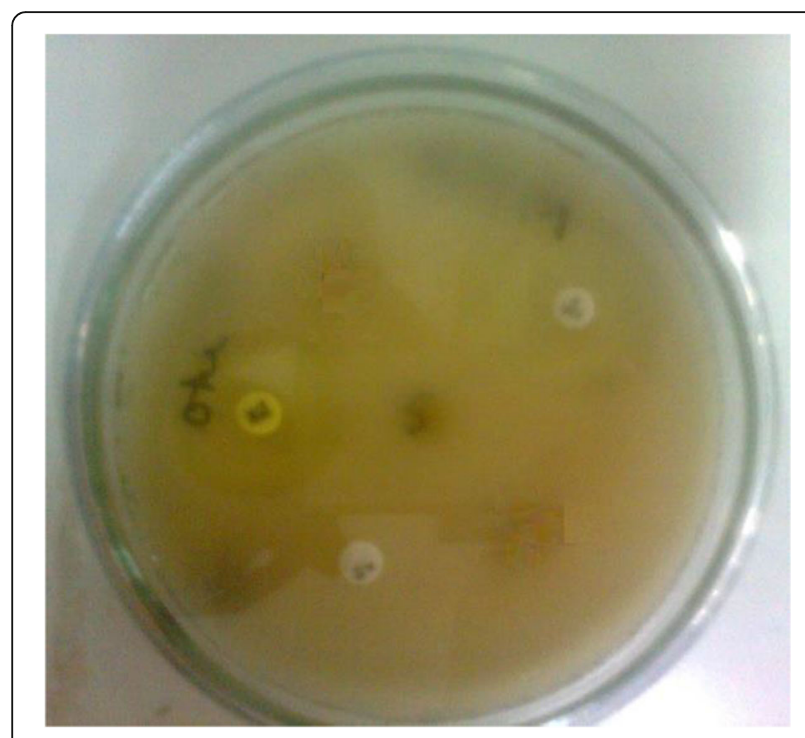

Fig. 5 Zone of Bacillus cereus for standard, and essential oil at $800 \mu \mathrm{g} /$ well system [48]. Furthermore, root parts of Anethum sowa L. herb is not usually consumed, it is wasted mostly. The present investigation will be helpful for Ayurvedic and pharmaceutical industries to assess the essential and toxic elemental level for medicinal preparation.

Thermo-gravimetry is a technique in which change in the weight of a substance is recorded as a function of temperature or time. This technique is useful for the pre-formulation study of herbal preparation through physical and chemical changes. It detects the impurity, identified the complex mixture and thermal stability of the plant samples [49]. In the first stage, broad and shallow endothermic effect on the DTA curve indicated a small loss in mass by a dehydration reaction. This peak is due to desorption of moisture of the root powder

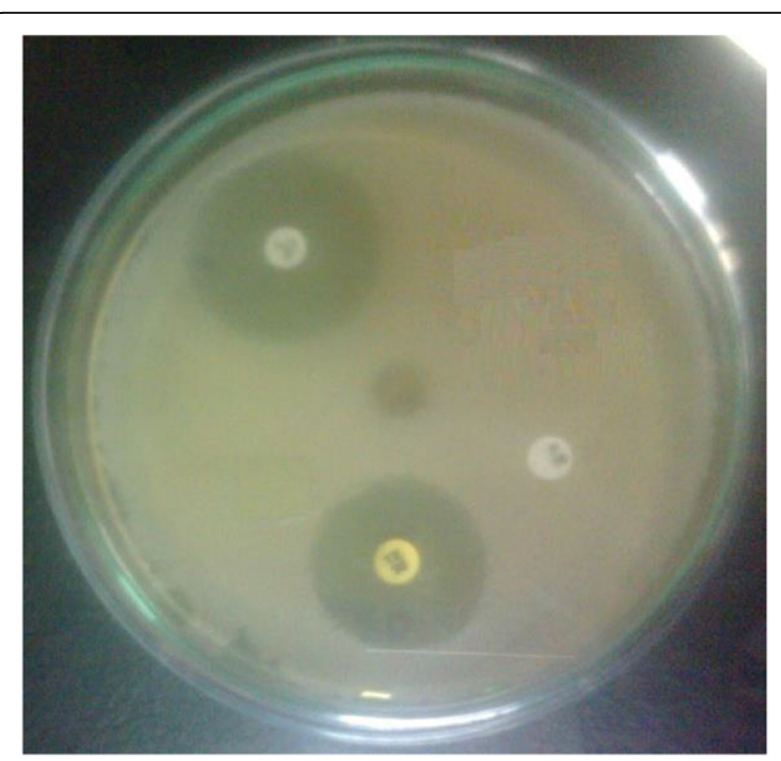

Fig. 6 Zone of $P$. aeruginosa for standard and essential oil at $800 \mu \mathrm{g} /$ well 
Table 15 Anti-fungal activity of Anethum sowa L. root essential oil

\begin{tabular}{|c|c|c|c|c|c|c|}
\hline \multirow[t]{3}{*}{ Fungi } & \multicolumn{4}{|c|}{ Zone of Inhibition in mm } & & \\
\hline & \multicolumn{3}{|l|}{ Essential oil } & \multirow{2}{*}{$\begin{array}{l}\text { Fluconazole } \\
100 \mu \mathrm{g} / \text { well }\end{array}$} & \multicolumn{2}{|c|}{$\mathrm{MIC} / \mathrm{MBC}(\mu \mathrm{g} / \mathrm{mL})$} \\
\hline & 400 mg/well & 600 mg/well & $800 \mu \mathrm{g} /$ well & & Essential oil & Fluconazole \\
\hline Candida albicans & - & 3 & 7 & 23 & $125 / 500$ & $62.5 / 250$ \\
\hline Aspergillus niger & - & 5 & 9 & 16 & $250 / 500$ & $125 / 500$ \\
\hline Sacharomyces cerevaceae & - & 4 & 7 & 10 & $62.5 / 250$ & $62.5 / 250$ \\
\hline Trichoderma sp. & - & - & - & 9 & $250 / 500$ & $125 / 500$ \\
\hline
\end{tabular}

material together with the evaporation of volatile components or essential oils. The chemical reaction was occurring in the second stage of decomposition by a strong exothermic effect on the DTA curve. A mass loss of the DTG curve was verified due to the elimination of moisture retained in this material. In the second stage, the highest mass loss was reflected by the TG and DTG curves which are due to the destruction and combustion of compounds contained in the root samples. The behaviour of the pyrolysis curve indicated hemi-cellulose and cellulose decomposition, as well as the loss of remaining adsorbed moisture. Lignin decomposition indicated that this structure presents a higher stability than hemi-cellulose and cellulose. The last stage indicated that the presence of oxides (mainly those of aluminium and silicon), which were stable at higher temperatures. The last stage was also associated with a large exothermic effect.

The essential oils and extracts of the medicinal plants have been used for food preservation, scenting agent and as a traditional healthcare since thousands of years [50]. In the GC-MS analyses, apiol and m-diaminobenzene were found the major constituents of $A$. sowa root essential oil. It was reported that apiol (20\%) was found as the main compound in the root essential oil of Anethum graveolens L. [7]. In the earlier studies, phenylpropanoid compounds were the rich level in leaf and stem part of A. sowa L. [51, 52]. On the other hand, apiol was also found in some umbelliferae plants like parsley (Petroselinum sativum and Petroselinum crispum) which have accounted for 18.23 and $17.54 \%$ respectively [53, 54]. Moreover, m-diaminobenzene (68.2\%) was also found as the highest amount in other Apiaceae plant (Ligusticum jeholense) essential oil [55]. On the other hand, carvone (27.8\%) was found the main predominant compound in Anethum graveolens L. followed by limonene (15.5\%), $\alpha$-phellandrene (14.7\%) and apiol (3.1\%) [9] while carvon, limonene and $\alpha$-phellandrene were totally absent in the present study. The variations of oil composition with Anethum graveolens species may be due to plant genetic base, development and mostly different environmental conditions.

The oil exhibited marked DPPH free radical scavenging activity in a concentration-dependent manner. The antioxidant activity of the oil was evaluated by the decolorisation of stable DPPH radical due to its hydrogen donating ability. The absorption is stoichiometric with respect to the number of electrons taken up [56].

Apiol is the major component of the essential oil and it has contained two methoxy groups in the symmetrical position of the benzene ring. This methoxy $\left(-\mathrm{OCH}_{3}\right)$ group is a well-known strong electron donating group, which can increase the stability of the benzene ring and enhance the radical scavenging activity as a result [54]. Zhang [54] and Elisia [57] indicated that the antioxidant activity of apiol is much stronger than the myristicin. It was also reported that substitution on the indole benzene ring with a methoxy group had greatly enhanced the radical scavenging activity of the un-substituted compounds [58]. The addition of a methoxy group also confers antioxidant activity to the chalcones [59]. Therefore, the essential oil and its king compound apiol have contributed significantly the antioxidant property being reported for the first time. On the basis of present findings, the essential oil of Anethum sowa L. root may be the potent alternative as natural antioxidants.

The brine shrimp cytotoxicity of the plant extract represents a rapid, inexpensive and simple bioassay technique for cytotoxic and anti-tumor activity. This test is also considered to be phototoxic, pesticidal, trypanocidal, antitumor, anticancer, enzyme inhibition and ion regulation activities. The assay indicated that essential oil is half of the vincristine sulphate toxicity. The apiol was reported to decrease the proliferation of human colorectal carcinoma cells (COLO 205) [60]. Moreover, the acaricidal constituent of apiol was isolated by various chromatographic techniques from Petroselinum sativum seeds and showed very strong acaricidal activity. This activity could be related to allyl $\left(-\mathrm{C}_{3} \mathrm{H}_{5}\right)$ and methoxy $\left(-\mathrm{OCH}_{3}\right)$ functional groups [61]. The antiproliferative activity of apiol and myristicin of Athamanta sicula L. also reported on human chronic myelogenous leukemia, lung tumor and breast adenocarcinoma cell line activities [62]. Nonetheless, apiol is known to have powerful insecticidal and synergist effect [6]. Therefore, the cytotoxic activity of the essential oil is due to the apiol compound of the $A$. sowa root. Furthermore, this essential oil may be helpful for treatment of premature ageing 
and cancer therapy by preventing oxidative damage through lipid peroxidation. Though it is the first report of cytotoxic activity on the brine shrimp, extensive studies are to be needed to assess the anticancer activity on the cell line of the essential oil and its isolated compound apiol.

The antimicrobial activities are responsible for oxygenated monoterpenes [63]. The appreciable antimicrobial activity of the essential oil of Anethum sowa L. may be attributed to the presence of monoterpenes compounds in the oil. On the other hand, the activity of the essential oil can be explained by the chemical structure of the major constituents of the oil. Apiol has a nucleus containing a polar functional group that is known to form hydrogen bonds with the active sites of the target enzyme [64]. It is assumed that the antimicrobial activity may be responsible for its apiol constituents, on the basis of that mechanism. The Gram-positive bacteria are generally more sensitive to the spice and herb essential oil than Gram-negative bacteria due to an outer membrane and a unique periplasmic space in the Grampositive bacteria [65]. The essential oil degrades the cell wall of the organism by interacting with the essential oil component which causes disrupt cytoplasmic membrane and damage membrane protein [66]. However, it did not completely follow the trend described above and showed the potent activity against Gram-negative bacteria. Nonetheless, the antimicrobial activity of essential oils may be due to the synergistic effect of the major compounds of the oil and also combined with another minor constituent. The results of the standard antibiotic showed the stronger activity against most of the bacterial species than the essential oil.

In the present study, the essential oils inhibited the fungal growth but their effectiveness varied. On the other hand, the essential oil was found to be more effective against fungi of the MIC and MBC assays. This activity may be responsible for the high content of apiol along with other minor constituents in the oil. Further investigations are needed to be carried out for the better understanding of the present issue.

\section{Conclusion}

As the chemical composition, as well as the pharmacological study of Anethum sowa L. root, have not been reported previously, it was undertaken for the present investigation. In the present results, we have found the Anethum sowa L. root as a rich source of mineral constituents along with amino acids. Inorganic elements remain complexed with organic ligands and make them bioavailable to the body system. The essential amino acids of the protein may prove its potentiality in medicinal preparation. The thermal analysis suggested that it is a simple, effective and rapid method to characterize the Anethum sowa L. species as well as to evaluation of phytotherapy. The current study of the essential oil showed weak antioxidant activity compared to ASA and BHT and also exhibited moderate antibacterial activity against Gram-negative bacteria than Gram-positive bacteria and fungi. This study contributes to knowledge of the chemical properties and also the biological significance of essential oil of Anethum sowa L. root as an aromatic, spice and medicinal plants. Several compounds of different polarity present in small amounts can also contribute to the biological activity. The results of the present studies will be helpful for herbal formulation and also for the basis of further studies.

\section{Additional files}

Additional file 1: Figure S1. GLC spectrum of standard fatty acids methyl esters (FAMEs). (DOCX $132 \mathrm{~kb}$ )

Additional file 2: Figure S2. GLC spectrum of pet.ether extract of Anethum sowa L. root. (DOCX $139 \mathrm{~kb}$ )

Additional file 3: Figure S3. GLC spectrum of hexane extract of Anethum sowa L. root. (DOCX $149 \mathrm{~kb}$ )

Additional file 4: Figure S4. Chromatogram of standard amino acids. (DOCX $108 \mathrm{~kb}$ )

Additional file 5: Figure S5. Amino acids chromatogram of Anethum sowa L. root. (DOCX $201 \mathrm{~kb}$ )

Additional file 6: Figure S6. Thermo-gravimetric spectrum of Anethum sowa L. root powder. (DOCX $125 \mathrm{~kb})$

\section{Abbreviations}

AAS: Atomic Absorption Spectrometry; Al: Atherogenic Index; AOAC: Association of Official Analytical Chemist; BHT: Tert-butyl-1-hydroxytoluene; DMSO: Dimethyl Sufoxide; DTA: Differential Thermal Analysis; DTG: Derivative Thermo Gravimetric; DWD: Dry Weight Basis; FAMEs: Fatty Acid Methyl Esters; GC-MS: Gas Chromatography and Mass Spectroscopy; ICP-MS: Inductively Coupled Plasma Mass Spectrometry; MBC: Minimum Bactericidal Concentration; MIC: Minimum Inhibitory Concentration; NA: Nutrient Agar, ASA: Ascorbic acid; PDA: Potato Dextrose Agar; PUFA: Poly Unsaturated Fatty Acid; R: Retention time; SFA: Saturate Fatty Acids; TGA: Thermo gravimetric analysis; TI: Thrombogenic Index

\section{Acknowledgements}

The authors would like to thank Bangladesh Council of Scientific and Industrial Research for laboratory facilities and awarding the Dr. Qudrat-iKhuda doctoral fellowship to the first author of this research work.

\section{Funding}

Not applicable.

\section{Availability of data and materials}

The datasets generated and/or analysed during the current study are available from the corresponding author on reasonable request.

\section{Authors' contributions}

MMS-e-In carried out hydro distillation of the essential oils, analysis fatty acid composition, antioxidant and cytotoxic assays and also made substantial contribution acquisition of data, analysis and drafted the manuscript. NS involved in the interpretation of the results and in the final revision of the work. MMR and MNHB acquired and analyzed the GC-MS data. MAA conducted the elemental assays. MNH played a major role in the experimental procedures of the antibacterial and antifungal activities. MMR performed the amino acid analysis. SKR designed the study and participated in plant selection and collection, thermal analyses and correction of the manuscript. MRI supervised the work, evaluated the results and corrected the manuscript for publication. All authors read and approved the final manuscript. 


\section{Competing interests}

The authors declare that they have no competing interests.

\section{Consent for publication}

Not applicable.

\section{Ethics approval and consent to participate}

Not applicable.

\begin{abstract}
Author details
'Department of Chemistry, Jahangirnagar University, Savar, 1342 Dhaka, Bangladesh. ${ }^{2}$ Institute of National Analytical Research and Services, BCSIR Laboratories, Bangladesh Council of Scientific and Industrial Research, Dhaka 1205, Bangladesh. ${ }^{3}$ Food Toxicology Research Section, Institute of Food Science and Technology, Bangladesh Council of Scientific and Industrial Research, Dhaka 1205, Bangladesh. ${ }^{4}$ Industrial Microbiology Research Division, Institute of Food Science and Technology, Bangladesh Council of Scientific and Industrial Research, Dhaka 1205, Bangladesh. ${ }^{5}$ Plant Protein Research Division, IFST, Bangladesh Council of Scientific and Industrial Research, Dhaka 1205, Bangladesh. ${ }^{6}$ IFRD, Bangladesh Council of Scientific and Industrial Research, Dhaka 1205, Bangladesh.
\end{abstract}

Received: 23 January 2016 Accepted: 24 January 2017

Published online: 23 February 2017

\section{References}

1. Anonymous. The Wealth of India. A Raw Materials, vol. 1. New Delhi: Council of Scientific and Industrial Research; 1985. p. 272-5.

2. Chopra RN, Nayer SL, Chopra IC. A Glossary of Indian Medicinal Plants and Supplements, Publication and Information Directorate, vol. 3. New Delhi: CSIR; 1992. p. 216-7

3. Radulescu V, Popescu ML, Ilies DC. Chemical composition of the volatile oil from different plant parts of Anethum graveolens L. (Umbelliferae) cultivated in Romania. Farmacia. 2010:58(5):594-600.

4. Woolf A. Essential oil poisoning. J Clin Toxicol. 1999;37(6):721-7.

5. Sing G, Maurya S, Lampasona MPD, Catalan C. Chemical constituents, antimicrobial investigations and anti-oxidative potentials of Anethum graveolens $\mathrm{L}$ essential oil and acetone extract: part 52. J Food Sci. 2005;70(4):208-15.

6. Lichtenstein EP, Liang TT, Schulz KR, Schnoes HK, Carter GT. Insecticidal and synergistic components isolated from dill plants. J Agric Food Chem. 1974;22(4):658

7. Lawrence BM. Progress in essential oils. Perfume Flavor. 1985;10:29

8. Udagawa $Y$. Some responses of dill (Anethum graveolens $\mathrm{L}$ ) and thyme (Thymus vulgaries) grown in hydroponic to the concentration of nutrient solution. Acta Hortic. 1995:396:203-10.

9. Santos PAG, Figueiredo AC, Lourenco PML, Barroso JG, Pedro LG, Oliveria MM, Schripsema J, Deans SG, Scheffer JJC. Hairy root culture of Anethum graveolens (dill): establishment, growth, time-course of their essential oil and its composition with parent plant oils. Biotechnol Lett. 2002:24:1031-6.

10. Official Methods of Analysis. Association of Official Analytical Chemist. 14th ed. Sydney: Williams; 2005. p. 503-32

11. BP. British Pharmacopoeia. Appendix A: Vol IV. British Pharmacopoeia Commission, Market Tower, 1 Nine Elms Lane London, SWB 5NQ. 2004.

12. USP. United States of Pharmacopoeia. United States of Pharmacopoeia National Formulary USP30-NF25. General Test and Assay. Maryland: 12601 Twinbrook Parkway Rockville; 2007. p. 20852-1790.

13. Soxhlet F. Die gewichtsanalytische bestimmung des milchfettes. Dingler's Polytech J. 1879:232:461-5.

14. AOAC. Official Methods of Analysis. Association of Official Analytical Chemists. 14th ed. AOAC Official Method 28.059: Washington. DC; 1984

15. Ulbritch TLV, Southgate DAT. Coronary heart disease: seven dietary factors. Lancet. 1991;338:985-92. doi:10.1016/0140-6736(91)91846-M.

16. Anonymous. Amino acid analysis system instruction manual. Shimadzu HPLC amino acid analysis system. Kyoto: Shimadzu Corporation. Analytical Instrument Division; 1993. p. 63-5.

17. Clevenger JF. Apparatus for the determination of volatile oil. J Pharm Sci. 1928:17:345-9. doi:10.1002/jps.3080170407.

18. Brand-Williams W, Cuvelier ME, Berset C. Use of a free radical method to evaluate antioxidant activity. Lebensm Wiss Technol. 1995:28:25-30. doi:10.1016/S0023-6438(95)80008
19. Meyer BN, Ferrigni NR, Putnam JE, Jacobsen JB, Nicholsand DE, Mclaughlin U. Brine shrimp: a convenient general bioassay for active plant constituents. Planta Med. 1982;45:31-4.

20. Bauer AW, Kirby WMM, Sherris JC, Turck M. Antibiotic susceptibility testing by standardized single disc method. Am J Clin Pathol. 1966;44:493-6.

21. Rahman A-u, Choudhury MI, Thomson W. Bioassay techniques for drug development. Harwood academic publishers. 2005. p. 8.

22. Parish ME, Davidson PM. Methods for evaluation: In antimicrobials in foods. 2nd ed. New York: Marcel Dekker, Inc.; 1993. p. 597-615.

23. Burt S. Essential oils: their antibacterial properties and potential applications in foods. Rev Int J Food Microbial. 2004:94:223-53.

24. Finney DJ. Probit Analysis. 3rd ed. London: Cambridge University Press; 1971. p. 333.

25. FAO. The utility of tropical foods: Tropical beans. Food and Agricultural Organization Publication. 1989. p. 22-6.

26. Saleh-E-In MM, Roy SK. Studies on fatty acid composition and proximate analyses of Anethum sowa L. (dill) seed. Bangladesh J Sci Ind Res. 2007;42(4):455-64

27. Saleh-E-In MM, Roy SK, Islam MR. Fatty acid composition of dill (Anethum sowa L.) flower. Jahangirnagar Univ J Sci. 2009;32(2):1-8.

28. Vles RO, Gottemborg JJ. Nutritional characteristics and food uses of vegetable oils. In: Robbelen G, Downey RK, Ashri A, editors. In oil crops of the world. New York: McGraw Hill; 1989. p. 63-86.

29. Ramadan MF, Morsel JF. Neutral lipids classes of black cumin (Nigella sativa L.) seed oils. European Food Res Tech. 2002;214:202-6.

30. Bender A. Meat and meat products in human nutrition in developing countries: paper 53. Rome: FAO Food and Nutrition, FAO; 1992. p. 47-50.

31. Department of Health and Social Security. Diet and cardiovascular disease. London: HMSO, Report on Health and Social Subjects; 1984. p. 28.

32. Poppitt S, Keogh G, Mulvey T, Mcardle B, Macgibbon A, Cooper G. Lipidlowering effects of a modified butter-fat: a controlled intervention trial in healthy man. European J Clin Nutr. 2002:56:6471.

33. Lisiewska Z, Slupski J, Kmiecik W, Gebczynski P. Amino acid profile and protein quality of fresh and frozen dill depending on usable part of raw material, pre treatment before freezing and storage temperature of frozen products. Electronic J Polish Agric Univ. 2004:7(1):0.

34. FAO/WHO/UNU. Energy and protein requirements, WHO technical series No. 724. Geneva: WHO; 1985. p. 13-205.

35. Shewry PR, Napier JA, Tathan AS. Seed storage proteins: Structures and biosynthesis. Plant Cell. 1995;7:945-56.

36. Choudhury RP, Grarg AN. Variation in essential, trace and toxic elemental contents in Murrayakoenigii-A spice and medicinal herb from different Indian states. Food Chem. 2007:104(4):1454-63.

37. Brody T. Nutritional Biochemistry. San Diego: Academic; 1994.

38. Cerenak I, Vink R. Magnesium as a regulatory cation in direct and indirect traumatic brain injury. In Magnesium in the environment and organisms. Belgrade: Proceedings of the first symposium on magnesium; 1999. p. 10-4

39. Olabanji SO, Adesina SK, Ceccato D, Buoso MC, Moschini G. PIXE analysis of some medicinal plants usually extracted and drunk as a tea, beverage or used as spice or flavour in Nigeria. Mexico: Proceedings of the International Conference on PIXE and in Analytical Applications Puebla; 2007. p. 25-9.

40. Forrer R, Gautschi K, Stroh A, Lutz H. Direct determination of selenium and other trace elements in serum samples by ICP/MS. J Trace Elem in Med Biology. 1998;12:240-7.

41. FNB (Food and Nutrition Board). Dietary reference intakes for vitamin C, vitamin $E$, selenium, and carotenoids. Washington: Institute of Medicine, National Academy Press 2101 Constitution Avenue; 2000. p. 20418. http://www.nap.edu.

42. Macrae R, Robinson RK, Sadler MJ. Encyclopaedia of food science. Food technology and nutrition. San Diego: Academic; 1993. p. 7.

43. FDA. Food and Drug administration Code of Fed Reg, 40 CFR 101. Washington DC: FDA; 1999.

44. WHO. World Health Organization. Quality Control Methods for Medicinal Plant Materials. Geneva: WHO; 1998

45. Jack C, Clifton MS. Mercury Exposure and Public Health. Pediatric Clin N America. 2007;54(2):237.

46. Anonymous. Dictionary of Toxicology. Ernest $H_{\text {, Janice }} \mathrm{E}_{1}$ Chambers, Richard B, Mailman, editors. London: Macmillan Reference. 2nd ed. New York: Published in the US and Canada by Grove's Dictionaries; 1998. p. 55.

47. Godt J, Scheidig F, Grosse-Siestrup C, Esche V, Brandenburg P. The toxicity of cadmium and resulting hazards for human health. J Occup Med Toxicol. 2006;1:22. 
48. Heyes RB. The carcinogenicity of metals in humans. Cancer Causes Control. 1997;8:371-85

49. Mendhan J, Denny RC, Barnes JD, Thomas MJK. VOGEL's Textbook of Quantitative Chemical Analysis, (low price edition) Dorling Kindersley (India) Pvt; 2000. 6th ed. 2000. p. 503-22.

50. Lis-Balchin M, Deans SG. Bioactivity of selected plant essential oils against Listeria monocytogenes. J Appl Bacteriol. 1997;82:759-62.

51. Saleh-e-In MM, Sultana A, Husain M, Roy SK. Chemical composition of essential oil of Anethum sowa L. stem. Indian Perfumer. 2008;52(4):64-6.

52. Saleh-e-In MM, Sultana A, Husain M, Roy SK. Chemical constituents of essential oil from Anethum sowa L. herb (leaf and stem) growing in Bangladesh. Bangladesh J Sci Ind Res. 2010;45(2):173-6.

53. Romeilah RM, Fayed SA, Mahmoud GI. Chemical compositions, antiviral and antioxidant activities of seven essential oils. J Appl Sci Res. 2010;6(1):50-62.

54. Zhang H, Chen F, Wang X, Yao HY. Evaluation of antioxidant activity of parsley (Petroselinum crispum) essential oil and identification of its antioxidant constituents. Food Res Int. 2006;39:833-9.

55. Wang J, Xu L, Yang L, Liu Z, Zhou L. Composition antibacterial and antioxidant activities of essential oils from Ligusticum sinense and $L$. jeholense (Umbelliferae) from China. Rec Nat Prod. 2011;5(4):314-8.

56. Chen CW, Ho CT. Antioxidant properties of polyphenols extracted from green and black tea. J Food Lipids. 1995;2:35-46.

57. Elisia I, Kitts DD. The antioxidant potential of parsley and its constituents. CAB Rev: Perspect Agric Vet Sci Nutr Nat Res. 2008;3(076):1-14.

58. Benabadji SH, Wen R, Zheng JB, Dong XC, Yuan SG. Anti-carcinogenic and antioxidant activity of di-indolylmethane derivatives. Acta Pharmacol Sin. 2004;25(5):666-71.

59. Miranda CL, Stevens JF, Ivanov V, Mccall M, Balz F, Deinzer ML. Antioxidant and pro-oxidant actions of prenylated and nonprenylated chalcones and flavanones in vitro. J Agric Food Chem. 2000;48:3876-84.

60. Lien HM, Kuo PT, Huang CL, Kao JY, Lin H, Yang DY, Lai YY. Study of the anti-proliferative activity of 5-substituted 4,7-dimethoxy-1,3-benzodioxole derivatives of SY-1 from antrodiacamphorata on human COLO 205 colon cancer cells. Evidence-Based Comp Alternative Med. 2011; 2011: Article ID 450529. doi:10.1093/ecam/nep230.

61. Song HY, Yang JY, Suh JW, Lee HS. Acaricidal activities of apiol and its derivatives from Petroselinum sativum seeds against Dermatophagoides pteronyssinus, Dermatophagoides farina and Tyrophagusputre scentiae. J Agric Food Chem. 2011:59(14):7759-64. doi:10.1021/ff201945y.

62. Stefano VD, Pitonzo R, Schillaci D. Antimicrobial and antiproliferative activity of Athamant asicula L. (Apiaceae). Pharmacogn Mag. 2011;7(25):31-4.

63. Berger RG. Flavours and fragrances: Chemistry, bio-processing and sustainability. Heidelberg: Springer Verlag; 2007.

64. Farag RS, Daw ZY, Abo-Raya SH. Influence of some spice essential oils on Aspergillus parasiticus growth and production of alfatoxin in a synthetic medium. J Food Sci. 1989;54(1):74-6.

65. Nikaido H. Outer membrane. In: Neidhardt FC, editor. Escherichia coli and Salmonella typhimurium: Cellular and Molecular Biology. Washington, D.C: American society for Microbiology Press; 1996. p. 29-47.

66. Sikkema J, DeBont JAM, Poolman B. Interaction of cyclic hydrocarbons with biological membranes. J Biol Chem. 1994;269:8022-8.

\section{Submit your next manuscript to BioMed Central and we will help you at every step:}

- We accept pre-submission inquiries

- Our selector tool helps you to find the most relevant journal

- We provide round the clock customer support

- Convenient online submission

- Thorough peer review

- Inclusion in PubMed and all major indexing services

- Maximum visibility for your research

Submit your manuscript at www.biomedcentral.com/submit

\section{O) Biomed Central}

